\title{
Exergetic and Sustainability Analysis of an Intercooled Gas Turbine Cogeneration Plant with Reverse Osmosis Desalination System
}

\author{
Abdulrahman Almutairi*, ${ }^{*}$, Pericles Pilidis ${ }^{2}$, Nawaf Al-Mutawa ${ }^{3}$, Mohammed Al-Weshahi ${ }^{4}$ \\ 1 Researcher ,Cranfield University, School of Aerospace, Transport and Manufacturing, Power and Propulsion Department, Cranfield, \\ Bedfordshire MK43 OAL,UK (corresponding author).Email: a.s.almutairi@cranfield.ac.uk. \\ ${ }^{2}$ Professor,Cranfield University, School of Aerospace, Transport and Manufacturing, Power and Propulsion Department, Cranfield, \\ Bedfordshire MK43 OAL, UK \\ ${ }^{3}$ Assistant Professor, Kuwait University, College of Engineering and Petroleum, Alkhalidiya,P.O.Box 5969 Safat 13060, Kuwait \\ ${ }^{4}$ Assistant Professor, Shinas College of Technology, Engineering Department, Shinas,P.O.Box 77, Oman
}

\section{Abstract}

In this paper, an advanced cogeneration plant based on a $100 \mathrm{MW}$ aero-derivative intercooled gas turbine (ICGT) engine and large two-pass reverse osmosis (RO) desalination system is analyzed thermodynamically. The proposed model has been developed using the IPSEpro software package and validated with manufacturers' published data. Saline water is simulated using the latest physical properties available in the literature and treated as a real mixture. Combined energetic and exergetic performance criteria for the design of a cogeneration plant is presented as being, today, the most efficient method for accurate assessment of performance which also permits quantification of system deficiencies. The performance of the proposed plant was investigated using different loads, ambient temperatures, pressure ratios and feed water temperatures. The results show an intercooler system improves cogeneration plant performance despite having a negative impact on the combustion chamber performance because of its reduction of compressed air temperature.

The ICGT engine is considered to be the best available choice to integrate with an RO unit because of its high-pressure ratio and low power consumption in the compressors. From an operational perspective full load, low ambient and high feed water temperatures are highly recommended. The exergetic efficiency of the ICGT engine, RO system and cogeneration plant are shown to be $44.3 \%, 32.83 \%$ and $47.6 \%$ respectively. From a sustainability perspective, the exergetic-environmental efficiency is slightly affected by ambient temperature while highly affected by load variation. Based upon the obtained results, numerous possibilities are presented to improve the performance of cogeneration plant. 


\section{1- Introduction}

The rate of depletion of non-renewable energy and water has increased enormously over the last century to meet the demands of increased economic activities, rapid increases in population and changes in lifestyle which has had serious adverse effects on environmental sustainability. Cogeneration systems to supply power and clean water from a single fuel source have a relatively high performance, low production cost and environmental impact compared to separate power and desalination plants. The most common technology used for electrical generation today is the GT whereas in water technology reverse osmosis (RO) is predominant. In the current study, these two systems are integrated as shown in Figures 1 and 2.

Exergy represents the maximum obtainable work from a system under reversible conditions. Exergy analysis is a decisive tool to assess the efficiency of energy systems especially when the product has a different energy form and quality. It reveals the sources and magnitudes of irreversibilities within a system. Exergy analysis is governed by the first and second laws of thermodynamic, and it is not conserved and adjusted by waste exergy.

In last two decades, numerous exergy studies have been performed on RO plants in standalone mode, but only a few have focused on RO plants in cogeneration systems. Cerci (2002) performed an exergy analysis study for a $7250 \mathrm{~m}^{3} / \mathrm{d} \mathrm{RO}$ plant located in California and alternative designs were explored in order to improve plant performance. The exergetic efficiency of the plant was low, equal to $4.3 \%$, and the proposed alternative design had an exergetic efficiency of $4.9 \%$, only slightly higher than the original plant. In that study, the thermo-physical properties of seawater were treated as an ideal mixture.

Wanga and Tang (2013) produced an exergetic analysis of a two-stage RO desalination plant, which resulted in two main findings. First, increasing the number of stages raises the input pressure, resulting in higher exergy and total exergy destruction. Second, exergetic efficiency can be improved by heating the feed water and increasing product flow usage. Ternero, et al. 
(2005) conducted an exergetic study of a $21,000 \mathrm{~m}^{3} / \mathrm{d}$ RO plant located in Spain. The main observation was that about $80 \%$ of exergy destruction occurred in the core unit, which consisted of high pressure pumps, membrane modules and valve regulation. Aljundi (2009) introduced second-law analysis using actual plant data from a 1,600 $\mathrm{m}^{3} / \mathrm{d}$ RO plant located in Jordan. The results of this study show the highest exergy destruction occurred in the membrane modules and throttling valve, confirming the findings of Cerci (2002). Al-Zahrani et al. (2012) conducted a thermodynamic analysis of a RO desalination unit with energy recovery. Three configurations were introduced into the desalination unit; (i) a throttling valve in the rejection section, (ii) an hydraulic turbine and (iii) a pressure exchanger system (PX) used as an energy recovery device (ERD). The results showed that plant performance was significantly affected by applied pressure, feed water salinity and temperature. El-Emam and Dincer (2014) investigated the performance of a $7586 \mathrm{~m}^{3} / \mathrm{d} \mathrm{RO}$ desalination plant with an integrated energy recovery Pelton turbine, at different seawater salinity values. The exergy analysis showed that the energy recovery device reduced exergy destruction by $35.5 \%$, compared to expansion valves. The recovery ratio of ERD was inversely proportional to product unit cost.

Sharqawy et al. (2011b) carried out exergetic analysis on a RO desalination plant using the latest available thermodynamic properties of seawater instead of treating it as an ideal mixture consisting purely of $\mathrm{H}_{2} \mathrm{O}$ and $\mathrm{NaCl}$. The results showed a significant difference between the results obtained using an ideal mixture and real properties, especially with regard to exergetic efficiency and energy consumption values.

Mistry et al. (2011) carried out exergetic analysis for different desalination technologies using a new definition for useful exergy output. In their study, the exergetic efficiencies of RO, METVC, MED, and MSF were found to be $31.9 \%, 8.5 \%, 5.9 \%$ and 2.9\% respectively. Kempton et al. (2010) investigated the thermodynamic efficiencies and greenhouse-gas emissions for three alternative desalination technologies. The result show that the highest exergetic efficiency 
occur with RO at 30.1\% followed by 14.3\% MED and 7.7\% MSF. Dashtpour and Al-zubaidy (2012) applied energy analysis to a RO plant using new a scheme to reduce electrical power consumption per unit volume of fresh water. Farooque et al. (2008) conducted energetic analyses of RO plant utilizing energy recovery devices. According to the study, the power consumption of the high-pressure pump was highly dependent on ERD efficiency and seasonal operating conditions.

In recent years, several studies have proposed environmental indicators based on an exergy analysis. Midilli and Dincer (2009) developed new exergetic-environmental indicators for a polymer electrolyte membrane fuel cell in order to measure environmental impact and sustainability. Some of these indicators were applied by Aydin (2013) to an aeroderivative GT. In this context, the present authors (Almutairi et al, 2015a), have developed a new indicator, termed exergetic-environmental efficiency, which relates exergetic efficiency and power output with exhaust gas production. The exergetic-environmental efficiency is considered to be a good indicator for measuring environmental impact resulting from energy system emissions. The amount of carbon dioxide $\left[\mathrm{CO}_{2}\right]$ was selected as a parameter to represent exhaust gases, as it is highly affected by energy system efficiency. The exergetic-environmental efficiency can be expressed as the ratio between the actual values and the stoichiometric value of $\mathrm{CO}_{2}$.

This article describes a study in which energy and exergy analyses were performed on a cogeneration plant based on an advanced aero-derivative ICGT integrated with a two-pass large RO unit. The current study aims to contribute to the literature by:

* Developing a comprehensive model for a cogeneration plant based on exergy analysis using real data sets.

* Evaluating a two-pass RO desalination plant of an industrial scale using the most recent thermo-physical properties of seawater, treated as a real mixture.

Examining the effects of intercooling on exergy destruction of all components. 


\section{2- $\quad$ Cogeneration plant: system description}

In this study, a cogeneration system based on an ICGT engine and RO desalination plant was investigated, see Figure 1. The ICGT engine was inspired by the LMS 100 GE, a state-of-theart aero-derivative GT. The desalination plant was inspired by the Al Shuwaikh RO desalination plant, see Figure 2, which is located in the state of Kuwait. The validation of the two models using manufacturer's data is shown in Appendix-A.

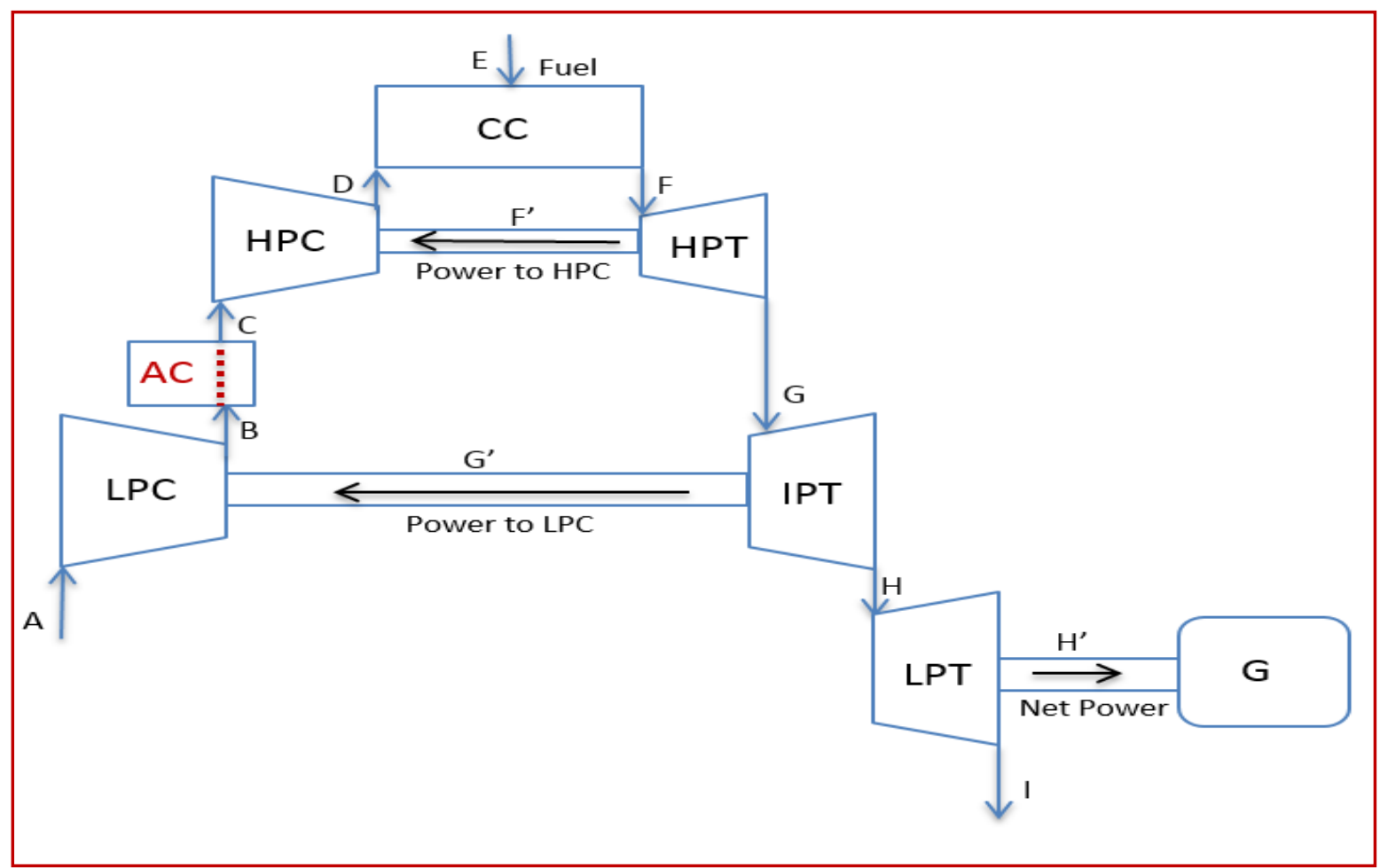

Figure 1. Schematic diagram for the intercooled gas turbine engine.

\subsection{Intercooled Gas Turbine Engine}

The ICGT engine is distinguished by intercooling modification of the GT system, and in today's market it has the highest claimed power output and efficiency (for simple cycles). Intercooling is an important technique that increases net GT power output by reducing compressor power consumption. With the intercooling system, the power consumption of the HPC is reduced, increasing overall efficiency. The ICGT system consists of three shafts (F', G' and H'), as shown in Figure-1. 


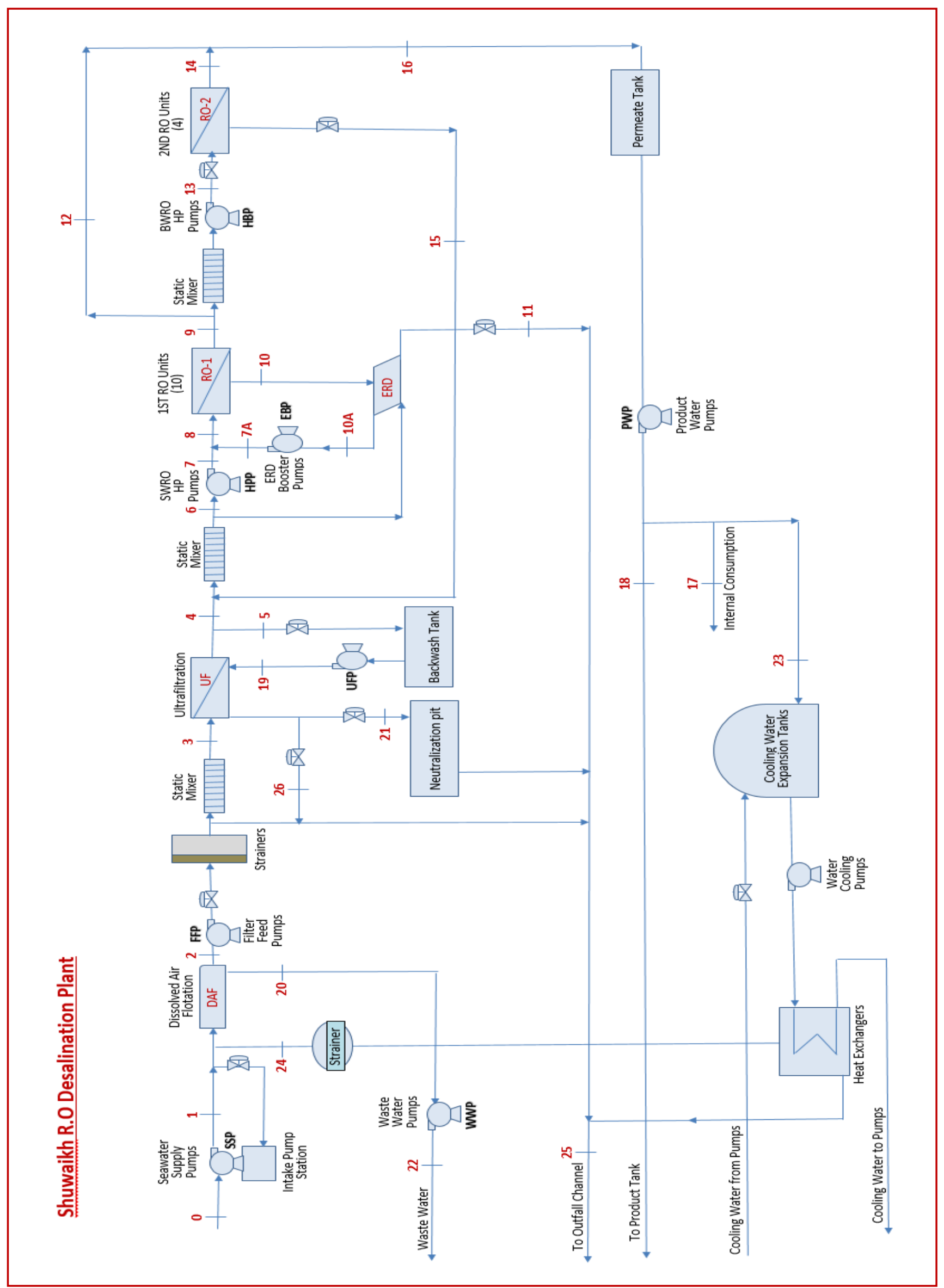

Figure 2. Schematic diagram for the Shuwaikh RO Desalination Plant (MEW, 2008). 
The first shaft is connected to the low-pressure components; the second, to the high-pressure components; and the third, to the power turbine. The cold section consists of the low-pressure compressor (LPC), high-pressure compressor (HPC) and the intercooler situated between them. The compressed air is delivered from the LPC to the intercooler to reduce the inlet temperature of the HPC by extracting heat. The work required to drive the HPC is reduced and leads to an increase in engine output power.

There is one negative impact of the intercooling process, the lower temperature of the air being delivered to the combustor, which increases the fuel consumption in the engine. The overall pressure ratio in the LPC and HPC compressors is 42. To reduce pressure losses two scroll casings have been introduced, one at the exit of the LPC before the intercooler, and the second at the inlet of the HPC. The high-pressure compressed air moves forward to the annular combustor and, mixed with fuel, results in hot, gaseous, products of combustion which are directed into the turbine section and expand through the high-pressure turbine (HPT), intermediate-pressure turbine (IPT), and low-pressure turbine (LPT) or power turbine (PT). The HPT and IPT are derived the HPC and LPC whereas the LPT produces the power output. The thermal efficiency and capacity of the ICGT engine are about $45 \%$ and 100 MW under International Standards Organization [ISO] conditions. The stream of exhaust gases exits from the stack at atmospheric pressure and temperature of about $685 \mathrm{~K}$. ICGT performance data is presented in Table 1.

\subsection{RO Desalination Plant}

The RO desalination plant is driven by the ICGT. A small portion of the power generated by the ICGT is directly consumed by the RO plant, and the majority is exported to the electrical network. The intake of the Shuwaikh RO desalination plant is on the coast of the Arabian Gulf, which has a high salinity, reaching $45,000 \mathrm{ppm}$. The design capacity of the inlet is about $425,000 \mathrm{~m}^{3} / \mathrm{d}$. The seawater supply pumps (SSP) draw seawater from the intake area and 
deliver it into the dissolved air flotation (DAF) system. The feed water is treated physically and chemically in the DAF system to remove or separate the colloidal solids, oils and greases. The feed water moves forward through strainers and a static mixer via filter feed pumps (FFPs). Next, the feed water is directed to the ultrafiltration (UF) system where large macromolecules, colloids, bacteria and proteins are removed. The UF system has a membrane with large pore sizes compared to the membrane modules in the RO unit.

Table 1. Performance data of proposed cogeneration system.

\begin{tabular}{|c|c|c|c|}
\hline \multicolumn{2}{|r|}{ Description } & Value & Unit \\
\hline \multirow{6}{*}{$\underline{U}$} & GT Power output & 98.70 & MW \\
\hline & Thermal efficiency & 45 & $\%$ \\
\hline & Heat rate & 7921.00 & $\mathrm{~kJ} / \mathrm{kWh}$ \\
\hline & Compressor Pressure ratio & 42 & ---- \\
\hline & Exhaust Mass flow & 222 & $\mathrm{Kg} / \mathrm{s}$ \\
\hline & Exhaust Temperature & 412 & ${ }^{\circ} \mathrm{C}$ \\
\hline \multirow{21}{*}{ 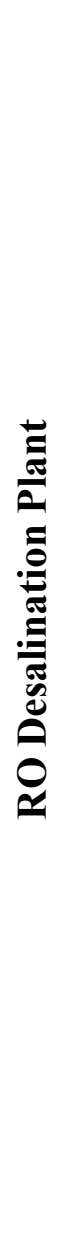 } & Number of SWRO stages & 10 & ---- \\
\hline & Number of BWRO nit stages & 4 & ---- \\
\hline & Seawater feed temperature & 15 & ${ }^{\circ} \mathrm{C}$ \\
\hline & Seawater salinity & 45000 & ppm \\
\hline & Design mass flow rate & 4921.1 & $\mathrm{Kg} / \mathrm{s}$ \\
\hline & Permeate mass flow rate & 1611.1 & $\mathrm{Kg} / \mathrm{s}$ \\
\hline & Rejected mass flow rate & 3342.8 & $\mathrm{Kg} / \mathrm{s}$ \\
\hline & SWRO permeate mass flow rate & 1750 & $\mathrm{Kg} / \mathrm{s}$ \\
\hline & SWRO bypass permeate mass flow rate & 361.1 & $\mathrm{Kg} / \mathrm{s}$ \\
\hline & SWRO permeate mass flow rate & 1250 & $\mathrm{Kg} / \mathrm{s}$ \\
\hline & BWRO rejected mass flow rate & 138.8 & $\mathrm{Kg} / \mathrm{s}$ \\
\hline & Permeate salinity & less than 200 & ppm \\
\hline & Brine salinity & 66279 & ppm \\
\hline & SSP discharge pressure & 2.5 & bar \\
\hline & FFP discharge pressure & 5.5 & bar \\
\hline & UF Backwash discharge pressure & 4.5 & bar \\
\hline & ERD booster pump discharge pressure & 66.7 & bar \\
\hline & SWRO HPP discharge pressure & 66.7 & bar \\
\hline & BWRO HPP discharge pressure & 13.7 & bar \\
\hline & SWRO recovery ratio & 42 & $\%$ \\
\hline & BWRO recovery ratio & 90 & $\%$ \\
\hline
\end{tabular}


The treated feed water is mixed with brackish water from the second pass RO unit, in the static mixer, then moves to the high-pressure pump (HPP). After that the high pressure feed water is mixed with the discharge stream from the ERD booster pumps, after which it enters the first RO unit (which consists of 10 stages). The exit stream splits into two main streams with different salinities. The permeate exiting from the first unit is also divided into two streams, the first is used as a feed to the second RO unit (4 stages) while the second blends with the permeate stream exiting from the second $\mathrm{RO}$ unit and is moved to the product tank by the product water pump. The product stream has a capacity of $136,000 \mathrm{~m}^{3} / \mathrm{d}$ with a salinity less than $200 \mathrm{ppm}$. The brine water of the first RO units returns to the main stream after passing through the pressure exchanger and booster pumps. The exiting brine water from the second $\mathrm{RO}$ unit is also returned to the main stream and mixes with the feed water, but after the UF system has reduced its salinity. The pressure exchanger system reduces the energy consumed in the first RO unit by about $50 \%$, especially at high feed salinity. The RO desalination plant contains a sophisticated pretreatment process prior to the thermal processes and which requires more than twenty different chemicals to protect the RO unit during its operation (Darwish, 2014). The RO desalination plant performance data is also shown in Table 1.

\section{3- Methodology}

Comprehensive energetic and exergetic studies were performed for a simulated cogeneration system inspired by real power generation and desalination units. The proposed system performance was investigated at different loads, ambient temperatures, feed water temperatures and pressure ratios. The following assumptions were made about the cogeneration system :-

- The proposed model operated at steady state conditions.

- Intake air and combustion products in the ICGT could be treated as ideal gas mixtures.

- The effects of kinetic and potential exergies could be omitted.

- Combustion was complete, and $\mathrm{N}_{2}$ was inert. 
- The supplied fuel was natural gas.

- The pump efficiency was 75\%, as published in (Kahraman and Cengel , 2005).

- The intake conditions were $288 \mathrm{~K}$ and $45000 \mathrm{ppm}$, and these were taken as the reference state.

\subsection{Seawater thermo-physical properties}

The modelling developments reported here and previously (Almutairi et al, 2016), have taken into account the thermophysical properties seawater, its composition and, particularly, chemical exergy. This is considered important because seawater contains a strong electrolyte which makes the ideal mixture concept inapplicable. Treating seawater as an ideal mixture produces unrealistic negative exergetic values in the different streams which offends against the second law of thermodynamics where the exergy must be equal to, or greater than zero. Nevertheless. for the sake of simplicity, some researchers such as (Hou et al. , 2007) have assumed seawater to be pure water. Ignoring the low salt percentage in seawater will have adverse effects on desalination plant design (Sharqawy et al. , 2010). However, the present study uses the latest published data on thermo-physical properties as given by Sharqawy et al. (2011a). The calculations and results for density, specific enthalpy, specific entropy and chemical potential are given Appendix-B.

\subsection{Energy analysis}

Exchange of energy for any system results in work and heat transfer through a specified domain. Conservation of energy maintains the sum of all energies in that region is constant because internal losses are not considered. For a generally steady state condition the energy equation state can be expressed as:

$$
\dot{\mathrm{Q}}-\dot{\mathrm{W}}=\Delta \mathrm{H}+\Delta \mathrm{Ke}+\Delta \mathrm{Pe}
$$

The heat transfer and work done are represented on the L.H.S. of Equation (1) while the change in enthalpy, kinetic and potential energies are respectively represented on the R.H.S. Energy 
analysis is considered a useful tool to calculate thermal efficiency, power output, heat release and enthalpies. Detailed calculations of air to fuel ratio in the combustion chamber is shown in Appendix-C.

\subsection{Exergy analysis}

Exergy analysis has become an important method for evaluating energy systems and is widely applied to determine type, location and magnitude of thermodynamics inefficiencies. Thus, it can play a decisive role in improving the performance of existing plants or design of new projects. Exergy analysis combines the principles of mass and energy conservation with the second law of thermodynamics. Unlike energy, exergy is not conserved and is highly effected by the quality of the energy. In the absence of nuclear reaction, surface tension, magnetism and electricity the total exergy will consist of four components; physical, chemical, kinetic and potential (Hepbasli , 2008). The exergy balance of a system is given by:

$$
\dot{E}_{x}=\dot{E}_{p h}+\dot{E}_{k e}+\dot{E}_{p e}+\dot{E}_{c h}
$$

Kinetic, $\dot{E}_{k e}$, and potential, $\dot{E}_{p e}$, exergies are commonly associated with the movement and elevation of particles, respectivly, but are omitted from the present study due to their negligibly small contibutions. Physical exergy consists of thermal and mechanical exergy and is defined as the maximum obtainable useful work from a unit mass of substance proceeding from a specified state (Ts, $p s)$ to the environmental state (To, po) (Querol et al., 2012). The physical exergy is given by the expression:

$$
\dot{E}_{p h}=\dot{m}\left[\left(h_{s}-h_{o}\right)-T_{o}\left(s_{s}-s_{o}\right)\right]
$$

Where the subscripts (s) refers to specified state and (o) for the corresponding environmental state. Once the specified temperature and reference temperature are equal, then for gases streams equation (3) becomes:

$$
\dot{E}_{p h}=\dot{m} R T_{o} \ln \frac{P_{S}}{P_{o}}
$$


When the system reaches full equilibrium (both physical and chemical) with the local environment, it is said to be in "dead state", and it has zero exergy. Chemical exergy is defined as the maximum energy that can be extracted from the stream as the flow reaches its dead state due to, for example, differences in molecular structure and concentration. The chemical exergy of the fuel, gas mixtures and saline water can be calculated using the following equations respectively:

$$
\begin{aligned}
& \dot{E}_{c h}=\dot{n} \overline{L H V} \\
& \dot{E}_{c h}=\dot{n}\left[y_{k} e_{k}^{-c h}+\bar{R} T_{o} \sum y_{k} \ln \left(y_{k}\right)\right] \\
& \dot{E}_{c h}=\dot{m} \sum w_{k}\left(\mu_{k}^{s}-\mu_{k}^{*}\right)
\end{aligned}
$$

Where the superscripts $\left(^{*}\right)$ refer to the dead state. The $\dot{\mathrm{n}}, \mathrm{e}_{\mathrm{k}}^{-\mathrm{ch}}$ and $\mu_{\mathrm{k}}$ represents number of mole rate, specific molar chemical exergy and chemical potential for component $k$ in the mixture. The specific molar chemical exergies are presented in the table for different substance as puplished in Bejan et al. (1996), Ahrendts (1980), Almutairi et al. (2015b) and Khaliq (2015).

The exergetic efficiency assesses the actual performance of an energy system from a thermodynamic view. The exergetic efficiency is defined as the ratio of product to fuel exergy for a system or component, i.e.:

$$
\eta_{e x}=\frac{\dot{E}_{p}}{\dot{E}_{f}}=1-\frac{\dot{E}_{d}+\dot{E}_{l}}{\dot{E}_{f}}
$$

Where $\dot{E}_{p}, \dot{E}_{f}, \dot{E}_{d}$ and $\dot{E}_{l}$ represent rates of production of exergy, fuel exergy, exergy destruction and exergy loss respectively. Exergy destruction is associated with irreversibilities within a component whereas exergy loss relates to energy emitted to the environment during the process or at the end. Inlet exergy to the component is always higher than outlet exergy by the value of the waste exergy as shown in the following equation. 


$$
\dot{E}_{e}=\dot{E}_{i}-\dot{E}_{d}-\dot{E}_{l}
$$

The exergy loss $\dot{E}_{l}$ for a certain component is equal to zero at the adiabatic condition. In the desalination process, the minimum work of separation represents exergy product whereas the fuel exergy is equal to electrical energy supplied to the system. Hence, the exergetic efficiency of RO system can be written as:

$$
\eta_{e x}=\frac{\dot{W}_{\min }}{\dot{E}_{f}}
$$

\subsection{Sustainability Indicator}

Exergy plays an important role in sustainable development, because it offers a common basis of assessment for diverse energy resources, and addresses concerns about the quality and quantity of energy. Environmental impact decreases and sustainability increases as the energy system's exergetic efficiency increases. Awareness of this important relationship between exergy and the environment may help reveal patterns in adverse changes to the environment, and assist researchers to better assess likely environmental damage. Rosen and Dincer (2012) reported three relationships between exergy and the environment, as illustrated in Figure 3.

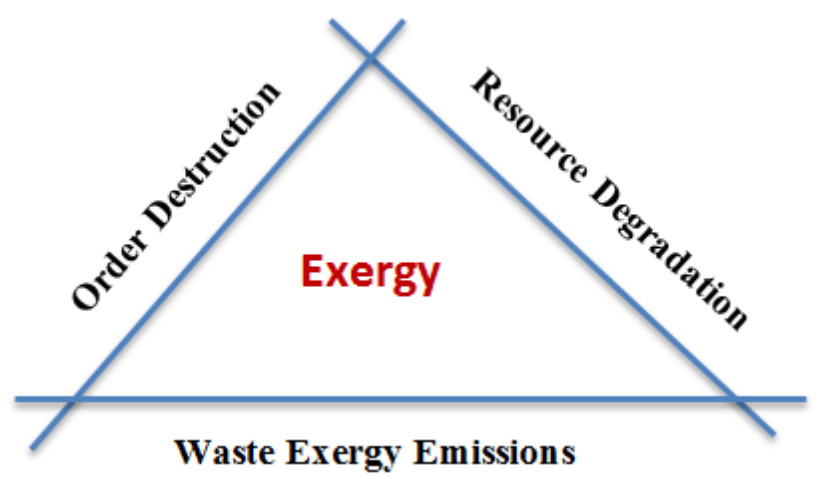

Figure 3: Exergy analysis with three forms of environmental damage.

Exergetic-environmental efficiency is considered to be a good indicator to assess likely environmental impact resulting from emissions from energy systems. The amount of $\mathrm{CO}_{2}$ in 
the exit gases was selected as the variable to represent emissions because it is highly affected by engine efficiency. Thus, exergetic-environmental efficiency is expressed as the ratio between actual values per MWh to the stoichiometric values of $\mathrm{CO}_{2}$, and can be written as:

$$
\xi_{C o 2}=\frac{\varphi_{a c}}{\varphi_{s t}}
$$

The stoichiometric value, $\varphi_{\text {st }}$, of $\mathrm{CO}_{2}$ can be calculated using molar analysis, whereas the actual value is obtained from the HEPHAESTUS generic combustor model. A cogeneration plant producing power and water as reported in the literature (Al-Weshahi et al. ,2013 ; Al-Sulaiman et al. , 2011 ; and Almutairi et al., 2016) generally considers the useful energy supplied to the desalination plant as addition energy equivalent to the amount of water produced. Thus the $\mathrm{CO}_{2}$ produced by the cogeneration of electricity and water has been expressed as:

$$
\varphi_{\text {cogen }}=\frac{\dot{m}_{\mathrm{CO} 2}}{\dot{\boldsymbol{W}}+\dot{\boldsymbol{Q}}_{\text {in }}}
$$

This approach does not reflect the real status of $\mathrm{CO}_{2}$ emission because it is based on the assumption of utilising an amount of energy with $100 \%$ efficiency, which is far from reality. The conflict comes from the nature of the product which is not energy and the low exergetic efficiency of desalination plants. However, using an energy input in the $\mathrm{CO}_{2}$ generation equation for a cogeneration plant can be justified as equivalent to having a stand-alone desalination plant using an industrial boiler, in spite of the different configurations between them. That shows substantial reduction in $\mathrm{CO}_{2}$ intensity per $\mathrm{MWh}$ and augments the cogeneration principle, but does not permit an accurate evaluation of $\mathrm{CO}_{2}$ emissions.

In this study, a new approach is proposed that is compatible with the desalination process as a low-grade heat recovery technology. The $\mathrm{CO}_{2}$ intensity equation uses minimum work of separation $\left(\dot{W}_{\min }\right)$ instead of energy input and can be written as:

$$
\varphi_{\text {cogen }}=\frac{\dot{m}_{\mathrm{CO} 2}}{\dot{W}+\dot{W}_{\min }}
$$




\section{4- Results and discussion}

This section presents the results of energetic and exergetic analyses of a cogeneration system (ICGT-RO) under different conditions. The effect of load variations, climatic conditions, pressure ratios, the number of stages and feed water temperatures have been investigated. The reference and dead state for water streams subject to the intake conditions $\mathrm{T}=288 \mathrm{~K}, \mathrm{P}=1.01$ bar, and $w_{s}=45,000 \mathrm{ppm}$. The streams of the topping cycle have the same reference conditions. The topping cycle and RO unit streams are denoted by letters and number respectively as illustrated in Figures 1 and 2. The exergetic data of the proposed cogeneration system at various locations are shown in Tables 2 and 3. The proposed model of the power and desalination plant were validated with manufacturer's published data and showed high compatibility. The validation was considered a necessary step prior to examining the model or commencing the analysis to maximise the reliability of the results.

Table 2. The exergetic data at various locations in RO plant.

\begin{tabular}{|c|c|c|c|c|c|c|c|c|}
\hline Point & Location & Fluid & $\begin{array}{l}\text { Mass } \\
\text { Flow } \\
(\mathrm{kg} / \mathrm{s}) \\
\end{array}$ & $\begin{array}{l}\text { Pressure } \\
\text { (bar) }\end{array}$ & $\begin{array}{c}\text { Salinity } \\
\text { (ppm) }\end{array}$ & $\begin{array}{c}\text { Enthalpy } \\
(\mathbf{k J} / \mathbf{k g})\end{array}$ & $\begin{array}{c}\text { Entropy } \\
\text { (kJ/kg. K) }\end{array}$ & $\begin{array}{c}\text { Exergy } \\
\text { Rate } \\
\text { (MW) }\end{array}$ \\
\hline 0 & Intake - SSP Inlet pump & Saline water & 4934 & 1.01 & 45000 & 59 & 0.21 & 0.00 \\
\hline 1 & SSP Outlet & Saline water & 4934 & 2.51 & 45000 & 59 & 0.21 & 0.72 \\
\hline 2 & DAF Outlet/ FFP Inlet & Saline water & 4603 & 2.26 & 45000 & 59 & 0.21 & 0.56 \\
\hline $2 \mathrm{~A}$ & FFP Outlet/ Strainers Inlet & Saline water & 4603 & 5.63 & 45000 & 60 & 0.21 & 2.05 \\
\hline 3 & UF Inlet & Saline water & 4573 & 5.51 & 45000 & 60 & 0.21 & 1.99 \\
\hline 4 & UF Outlet & Saline water & 3998 & 4.51 & 45000 & 59 & 0.21 & 1.35 \\
\hline 5 & Backwash Tank Inlet & Saline water & 575 & 4.01 & 45000 & 59 & 0.21 & 0.17 \\
\hline 6 & SWRO HPP Inlet & Saline water & 1773 & 4.51 & 43700 & 60 & 0.21 & 0.60 \\
\hline $6 \mathrm{~A}$ & ERD PX Inlet & Saline water & 2300 & 4.50 & 43700 & 60 & 0.21 & 0.78 \\
\hline 7 & SWRO HPP Outlet & Saline water & 1773 & 66.72 & 43700 & 68 & 0.22 & 11.27 \\
\hline $7 \mathrm{~A}$ & ERD BP Outlet & Saline water & 2314 & 68.00 & 48300 & 65 & 0.21 & 14.98 \\
\hline 8 & First RO Unit Inlet & Saline water & 4086 & 66.72 & 46300 & 67 & 0.21 & 25.94 \\
\hline 9 & First RO Unit Outlet & Fresh water & 1719 & 1.50 & 700 & 65 & 0.23 & 5.91 \\
\hline 10 & First RO Unit Outlet & Brine water & 2367 & 65.22 & 79400 & 63 & 0.19 & 16.14 \\
\hline $10 \mathrm{~A}$ & ERD Outlet/ BP Inlet & Saline water & 2314 & 63.10 & 48300 & 65 & 0.21 & 13.88 \\
\hline 11 & ERD Outlet/To Outfall & Brine water & 2354 & 1.30 & 75100 & 57 & 0.19 & 1.49 \\
\hline 12 & Bypass Line & Fresh water & 348 & 1.50 & 700 & 65 & 0.23 & 1.19 \\
\hline 13 & BWRO HPP Inlet & Fresh water & 1371 & 1.49 & 700 & 65 & 0.23 & 4.71 \\
\hline $13 \mathrm{~A}$ & BWRO HPP Outlet & Fresh water & 1371 & 13.71 & 700 & 67 & 0.23 & 6.39 \\
\hline 14 & Second RO Unit Outlet & Fresh water & 1232 & 1.50 & 100 & 65 & 0.23 & 4.38 \\
\hline
\end{tabular}




\begin{tabular}{|c|c|c|c|c|c|c|c|c|}
\hline Point & Location & Fluid & $\begin{array}{c}\text { Mass } \\
\text { Flow } \\
(\mathbf{k g} / \mathbf{s})\end{array}$ & $\begin{array}{c}\text { Pressure } \\
(\mathbf{b a r})\end{array}$ & $\begin{array}{c}\text { Salinity } \\
\mathbf{( p p m )}\end{array}$ & $\begin{array}{c}\text { Enthalpy } \\
\mathbf{( k J / k g})\end{array}$ & $\begin{array}{c}\text { Entropy } \\
(\mathbf{k J} / \mathbf{k g} . \mathbf{K})\end{array}$ & $\begin{array}{c}\text { Exergy } \\
\mathbf{R a t e} \\
\mathbf{( M W})\end{array}$ \\
\hline 15 & Second RO Unit Outlet & Brackish & 139 & 11.11 & 6100 & 66 & 0.23 & 0.48 \\
\hline 16 & Permeate Tank Outlet & Fresh water & 1580 & 1.50 & 200 & 65 & 0.23 & 5.59 \\
\hline $16 \mathrm{~A}$ & PWP Outlet & Fresh water & 1580 & 4.50 & 200 & 66 & 0.23 & 6.06 \\
\hline 17 & Internal Consumption & Fresh water & 32 & 4.50 & 200 & 66 & 0.23 & 0.12 \\
\hline 18 & To Product Tank & Fresh water & 1547 & 1.01 & 200 & 64 & 0.23 & 5.39 \\
\hline 19 & UFP Outlet/UF Inlet & Saline water & 575 & 4.51 & 45000 & 59 & 0.21 & 0.19 \\
\hline 20 & DAF Outlet/WWP Inlet & Saline water & 91 & 1.00 & 45000 & 59 & 0.21 & 0.00 \\
\hline 21 & TO Neutralization pit & Saline water & 91 & 1.00 & 45000 & 59 & 0.21 & 0.00 \\
\hline 22 & TO Waste Water & Saline water & 91 & 1.50 & 45000 & 59 & 0.21 & 0.00 \\
\hline 23 & TO CWE Tank & Fresh water & 0 & 4.50 & 200 & 66 & 0.23 & 0.00 \\
\hline 24 & Strainer Inlet & Saline water & 3023 & 1.10 & 68400 & 58 & 0.19 & 1.21 \\
\hline 25 & TO Outfall Channel & Brine water & 3023 & 1.10 & 68400 & 58 & 0.19 & 1.21 \\
\hline 26 & UF Outlet/To Outfall & Saline water & 488 & 2.51 & 45000 & 59 & 0.21 & 0.07 \\
\hline
\end{tabular}

Table 3. The exergetic data at various locations in ICGT engine at ISO condition

\begin{tabular}{|c|c|c|c|c|c|c|c|c|}
\hline Point & Location & Fluid & $\begin{array}{c}\text { Mass } \\
\text { Flow } \\
(\mathbf{k g} / \mathbf{s})\end{array}$ & $\begin{array}{c}\text { Temp. } \\
(\mathbf{K})\end{array}$ & $\begin{array}{c}\text { Pressure } \\
(\mathbf{b a r})\end{array}$ & $\begin{array}{c}\text { Enthalpy } \\
(\mathbf{k J} / \mathbf{k g})\end{array}$ & $\begin{array}{c}\text { Entropy } \\
(\mathbf{k J} / \mathbf{k g} . \mathbf{K})\end{array}$ & $\begin{array}{c}\text { Exergy } \\
\text { Rate } \\
(\mathbf{M W})\end{array}$ \\
\hline A & LPC Inlet & Air & 217.1 & 288 & 1.01 & 15.01 & 6.85 & 0.29 \\
\hline B & LPC Outlet/ Cooler Inlet & Air & 217.1 & 420.84 & 3.44 & 149.85 & 6.88 & 27.53 \\
\hline C & Cooler Outlet/ HPC Inlet & Air & 217.1 & 325.36 & 3.28 & 52.80 & 6.63 & 21.95 \\
\hline D & HPC Outlet/CC Inlet & Air & 217.1 & 701.55 & 42 & 444.73 & 6.69 & 103.09 \\
\hline E & CC Inlet & Fuel & 4.93 & 288 & 45 & 22.27 & -- & 222.89 \\
\hline F & CC Outlet/HPT Inlet & Exhaust Gases & 222.03 & 1490 & 39.82 & 1428.67 & 7.81 & 265.63 \\
\hline G & HPT Outlet/ IPT Inlet & Exhaust Gases & 222.03 & 1182.4 & 12.656 & 1037.66 & 7.85 & 173.17 \\
\hline H & IPT Outlet/ LPT Inlet & Exhaust Gases & 222.03 & 1073.5 & 8.02 & 903.14 & 7.87 & 145.39 \\
\hline I & LPT Outlet/Stack & Exhaust Gases & 222.03 & 685 & 1.013 & 444.85 & 7.95 & 38.72 \\
\hline
\end{tabular}

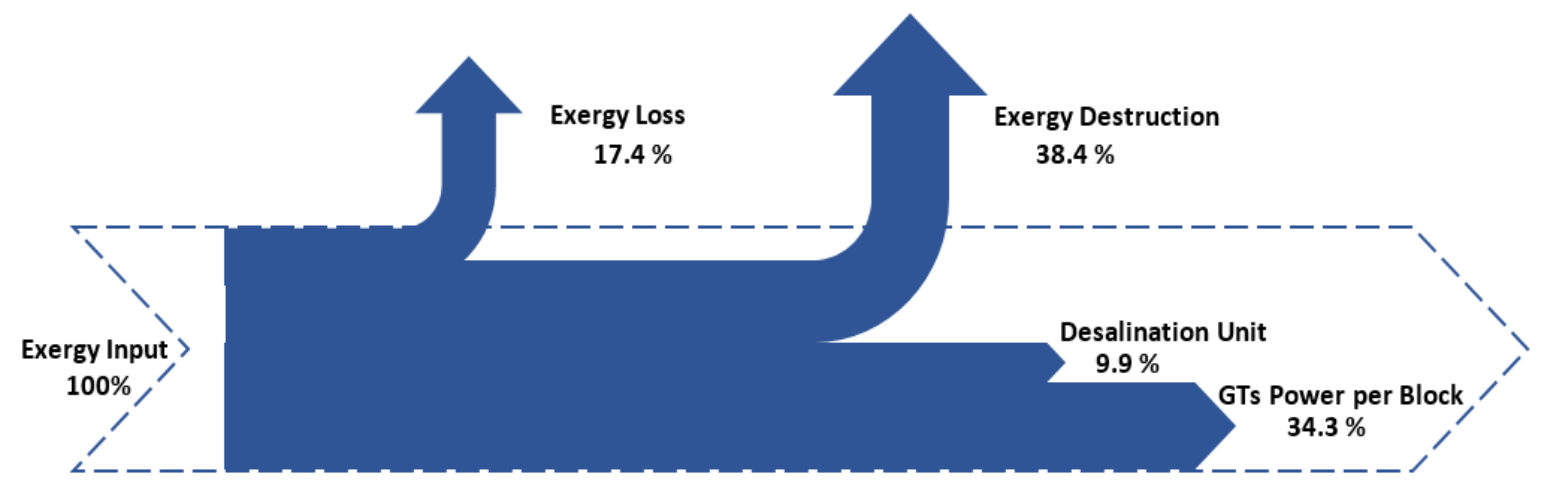

Figure 4. Exergy flow as a percentage of input fuel exergy.

Figure 4 uses a Grossman diagram to illustrate exergy flow across a cogeneration system at ISO conditions. Even though the ICGT contributes more useful exergy compared to the RO desalination unit, it has more exergy destruction. The fuel exergy of the RO unit is about 9.9 
$\%$, which is low, and shows how power production dominates plant performance. The system has a high exergy loss value that can be reduced by integrating the current system with a lowgrade heat recovery system to utilize heat contained in the gaseous products of combustion before they are emitted to the environment. The high value of exergy destruction in the combustion chamber of the proposed system open further possibilities to enhancing performance. The technique of improvement depends, of course, on type of component which is the source of the irreversibilities.

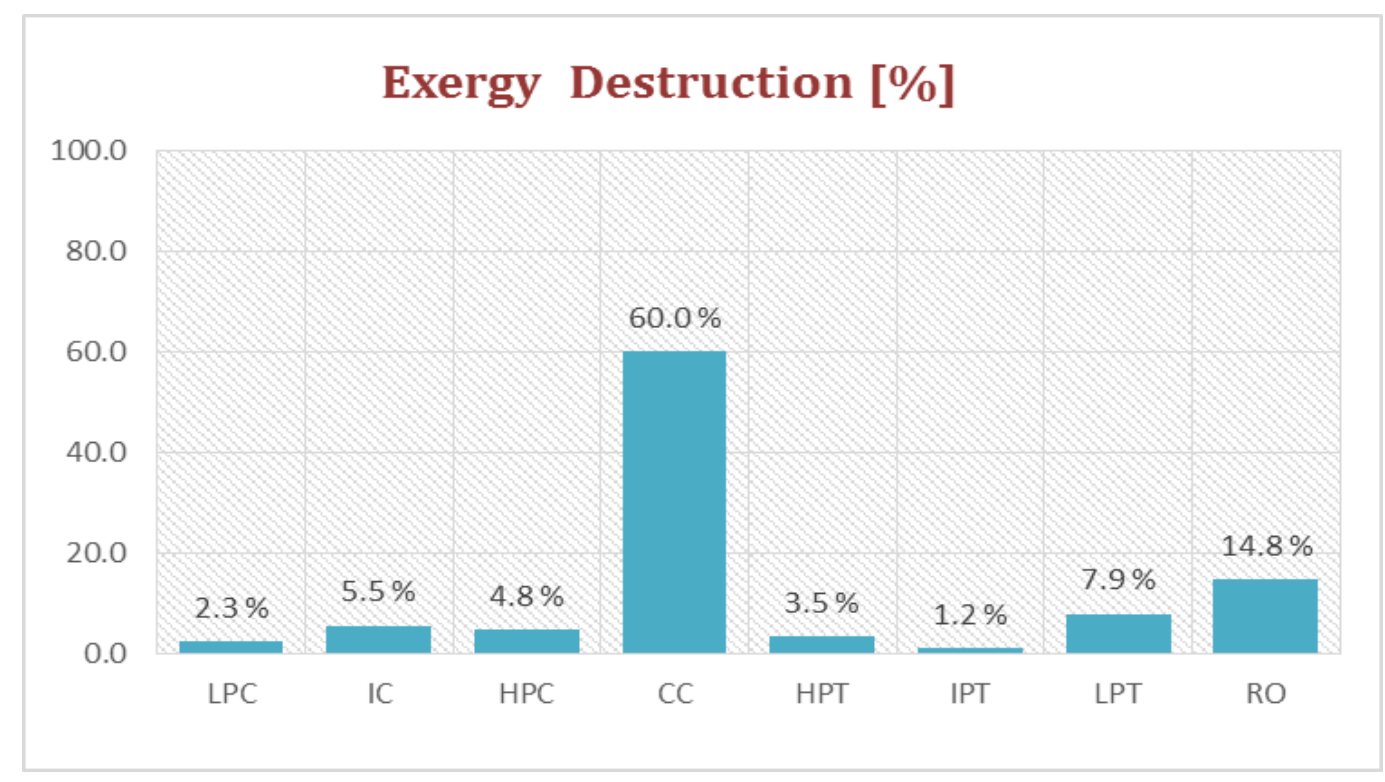

Figure 5. Exergy destruction as a percentage of total exergy destruction for all components in proposed cogeneration system at ISO condition.

Figure 5 shows the exergy destruction rate for each component as a percentage of total exergy destruction for all components in the system. The highest source of irreversibilities occurs in the combustion chamber due to turbulent mixing, chemical reactions, friction and heat loss. The exergy destruction in the combustor is about $60 \%$, higher than all the other components combined. This value can be reduced by preheating the fuel or compressed air and reducing excess air to near the stoichiometric value. Improving the mixing may also help to increase combustion efficiency. 
The RO unit constitutes the second source of irreversibilities of $14.8 \%$, which is relatively high compared to the exergy fuel input. This high level of waste exergy is attributed to friction, leakage losses and the large number of components in the RO unit. The LPT was third in the level of exergy destruction. It has a higher number of stages than either HPT or IPT; even the blade size creates more exergy destruction due to friction. The intercooler is next at $5.5 \%$, due to heat losses, temperature differences and friction. The effect of friction and aerodynamic loss predominate in the HPC component. The high fuel exergy and expansion rate are the main causes of irreversibilities within HPT. The LPC and IPT have lowest exergy destruction because both of them are mechanically coupled with a low rate of compression and expansion with respect to other rotating parts.

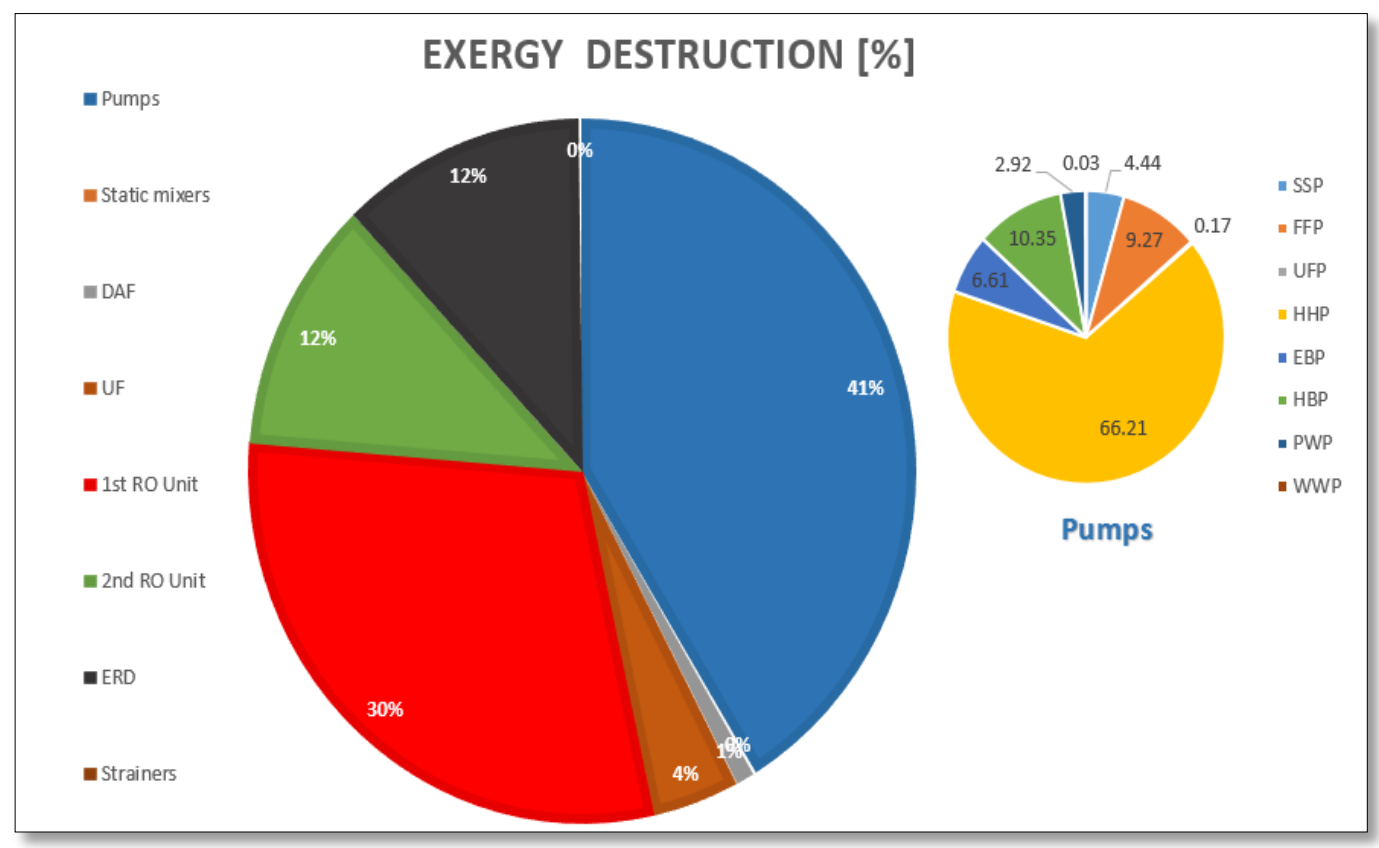

Figure 6. Relative exergy destruction as a percentage for the main RO unit components.

Figure 6 illustrates the relative percentages of total exergy destruction for the main components in the RO unit. The highest exergy destruction occur in the pumps (41\%) followed by the first membrane modules (30\%), then the second membrane modules and Pressure Exchanger-PX (both at 12\%). The high pressure pumps in SWRO (HHP) and BWRO (HBP), represent over $76 \%$ of pump exergy destruction. That can be reduced by using more efficient pumps. The 
high exergy destruction in the membrane modules may be attributed to fouling, hydraulic resistance and concentration polarization, thus improved membrane design could significantly enhance RO performance. The main sources of irreversibilities in the PX are friction and mixing. The membrane modules and PX have the same percentage of exergy destruction, but the latter has more potential for reducing both energy consumption and cost. In the current model the Shuwaikh RO plant used a PX, so there is a high potential for improvement using the more advanced isobaric, or pressure-equalising ERD.

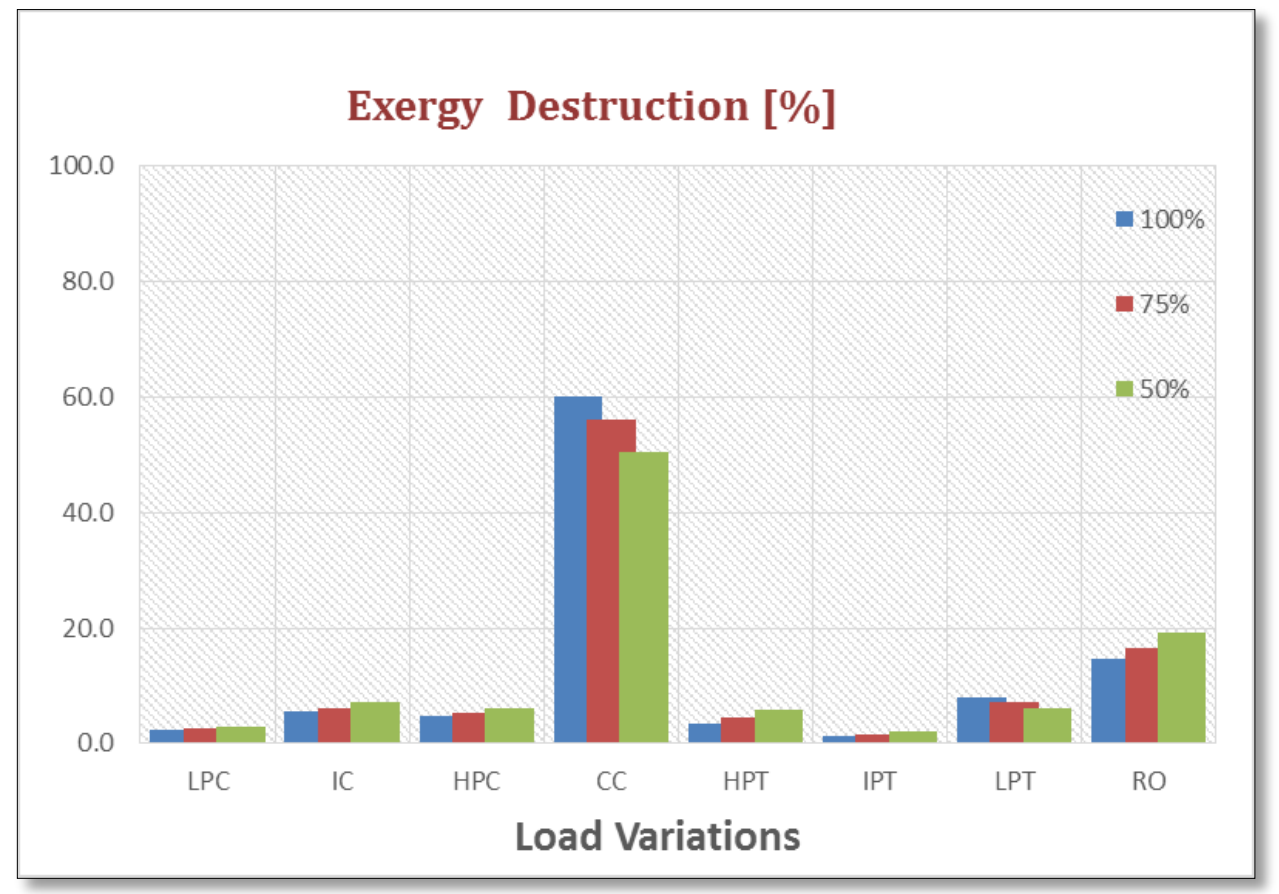

Figure 7. Relative exergy destructions for different loads for proposed cogeneration system under ISO conditions.

The effect of load variation on exergy destruction for all plant component is shown in Figure 7. The load variations are controlled mainly by electrical grid demand, which will vary during the day and with the season. The range shown is between minimum safe load (50\%) and full load, at design conditions. These two limit may change slightly with off-design conditions. In general, the highest exergetic efficiency is achieved at full load, but exergy destruction with load varies according to the component being considered. The exergy destruction in the combustion chamber decreases as the load decreases due to a reduction in the rate of fuel 
consumption. The proportional reduction in heat input is lower than power output, which explains the reduction in exergetic efficiency as the load decreases.

The expansion rate in the power turbine (LPT) reduced with load reduction and that caused a drop in exergy destruction level. The HPT and IPT have the same trend as HPC and IPC due to the mechanical coupling between them. Reducing the load increases exergy destruction because the fuel exergy relative to the expansion rate is increased. The intercooler in the ICGT has a higher irreversibilities level because the fall in exergy destruction rate is less than the total value of exergy destruction.

The relation between power to water ratio and exergetic efficiency is directly proportional. The exergy destruction in the RO unit with respect to total exergy destruction increases at part load whereas it registered the minimum value at full load.

In accord with the above results it is highly recommended to always operate the GT at full load, and the cogeneration system at high power to water ratio.

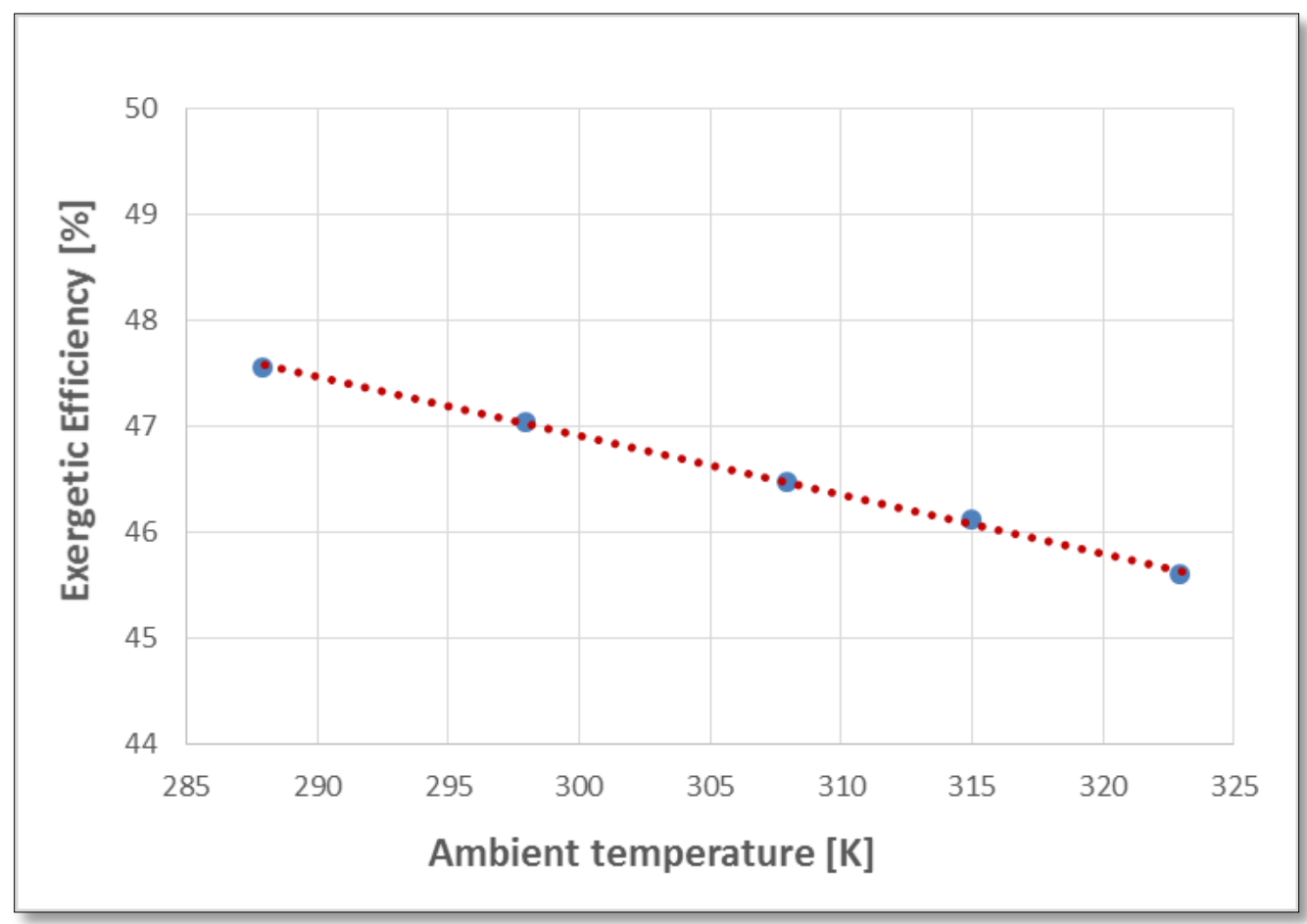

Figure 8. Exergetic efficiency versus and ambient temperatures for ICGT-RO cogeneration plant. 
The exergetic efficiency of a cogeneration plant varies with ambient temperature, see Figure 8. The variation in ambient temperatures is considered a good indicator of climate change. The effect of ambient temperature on plant performance was reduced due to the presence of intercooling. Ambient temperature effects are confined to LPC components, due particularly to increasing power consumption to compensate for the decrease in air density with increase in ambient temperature. Rising ambient temperature lead to a reduction in exergetic efficiency and the relation between them is inversely proportional. The exergy destruction in the LPC increases because of increasing fuel exergy in order to compensate for change in air density.

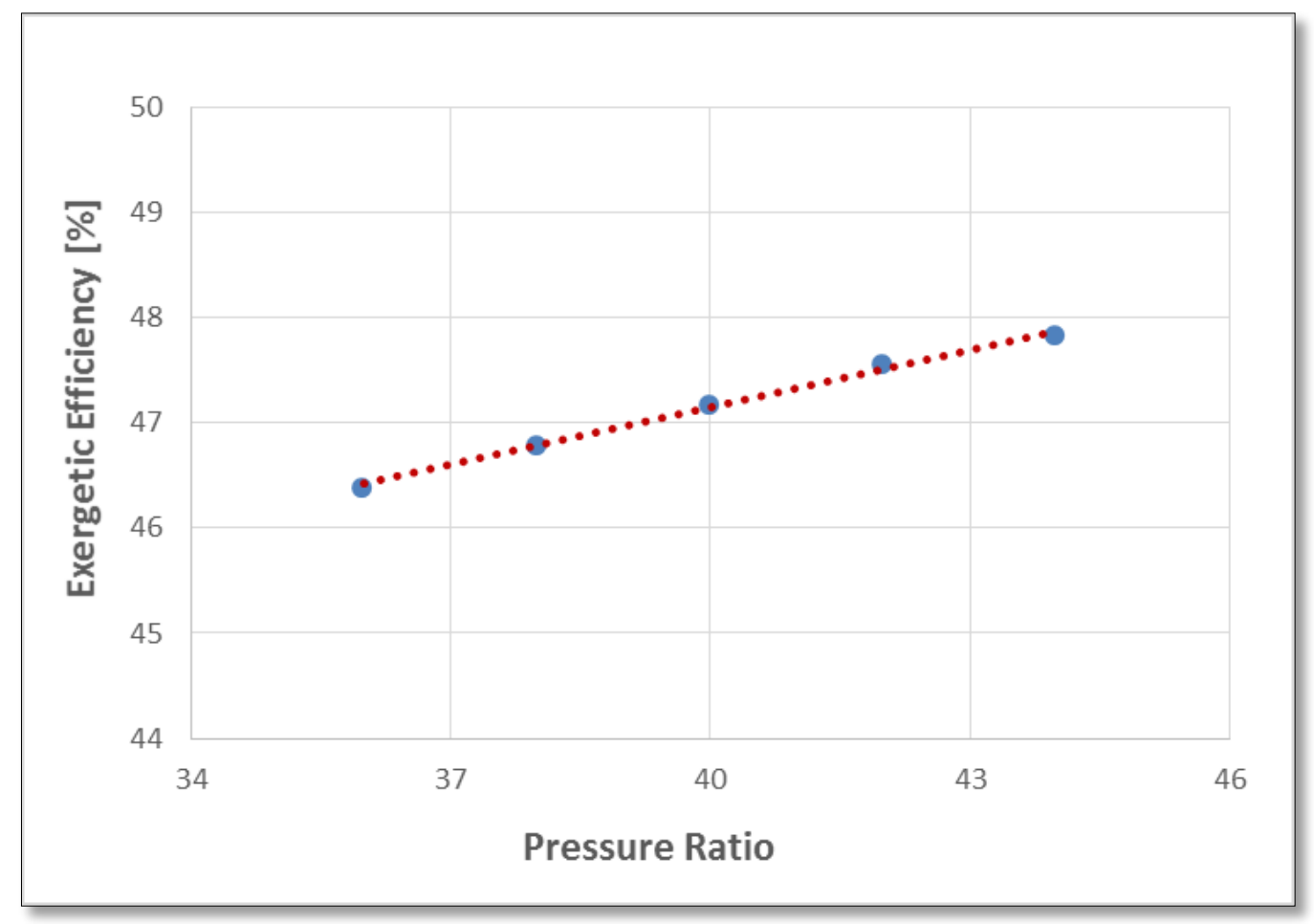

Figure 9. Exergetic efficiency versus and pressure ratio for ICGT-RO cogeneration plant.

Figure 9 shows the effect of variation of pressure ratio on plant performance. The exergetic efficiency of the cogeneration plant rose as the pressure ratio increased due to the increase in temperature of the compressed air temperature entering the combustion chamber. Hence, the amount of fuel required to meet the high-pressure turbine requirements decreased. The energy consumed by the compressors was less than the energy saved by the reduction in fuel 
consumption and that raised the exergetic efficiency as the pressure ratio increased. The ICGT has the highest pressure ratio as well as efficiency among all aeroderivative GT engines used for power generation today. Designing and/or operating the compressor at a high-pressure ratio will be beneficial from a performance perspective.

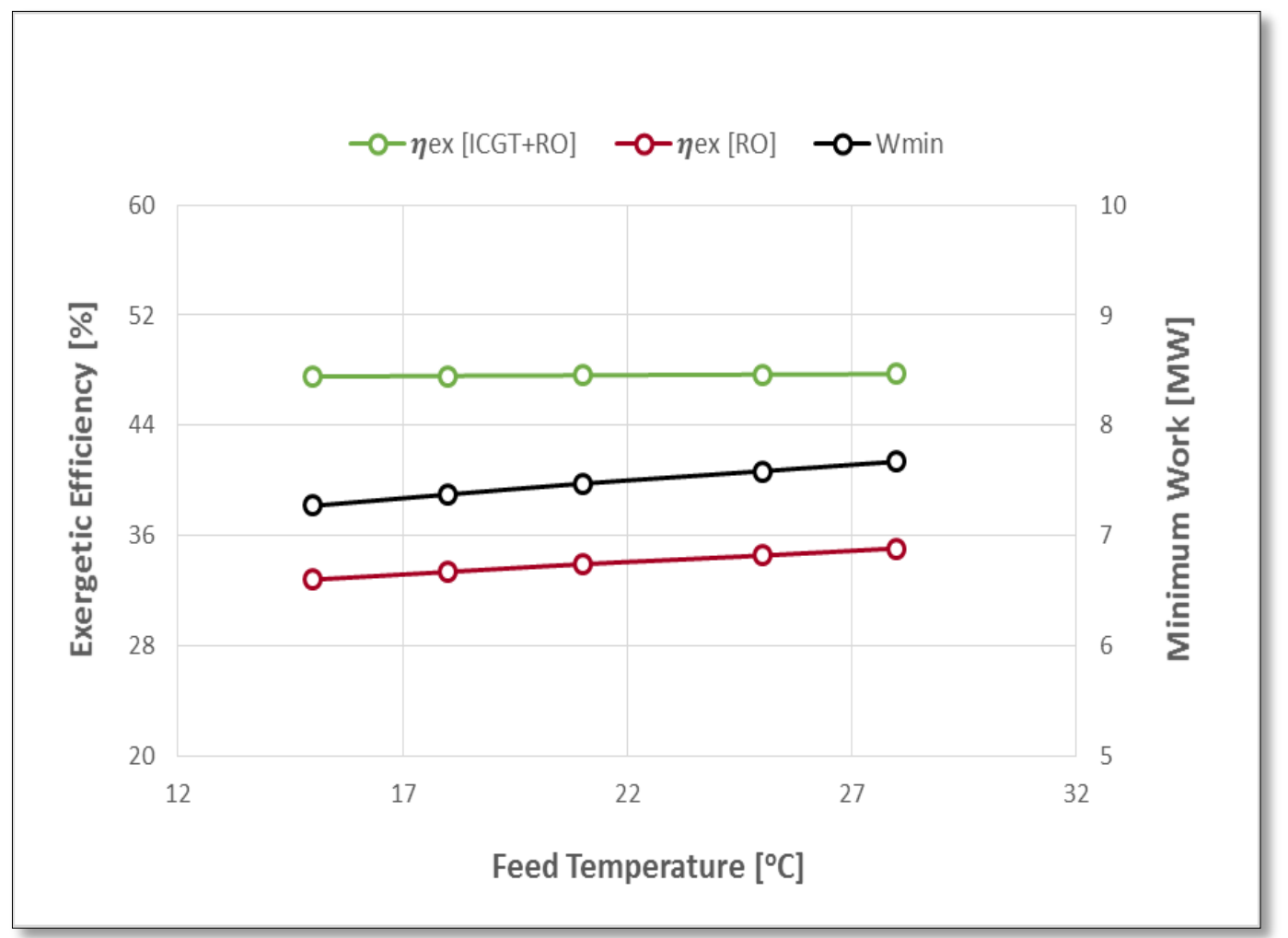

Figure 10. Exergetic efficiency and minimum work of separation versus feed temperature.

The sea water feed temperature significantly effect on RO unit performance as shown in Figure 10. It is well know that the sea water temperature in the Arabian Gulf varies from $10^{\circ} \mathrm{C}$ to $32^{\circ} \mathrm{C}$ with seasonal changes. This fact confirms the importance of investigating feed temperature either in the design or operational stages. The exergetic efficiency of the RO unit increased as feed temperature increased due to reduction in fuel exergy input and increasing minimum work of separation. Increase in feed temperature from $15^{\circ} \mathrm{C}$ to $28^{\circ} \mathrm{C}$ increased $\mathrm{RO}$ unit exergetic efficiency uniformly by $2.26 \%$, this was due largely to the increased value of minimum work of separation. Such a result strongly supports the hybridization of RO plant with thermal desalination or steam power plants in order to provide high temperature feed water. The 
exergetic efficiency of the cogeneration plant remained almost constant because the amount of energy saved in the RO unit was so small compared to the total energy consumed by the plant as a whole.

Figure 11 shows the environmental impact of the proposed system at the different operating conditions. The ICGT can be subject to part load due to variations in electrical network demand, which are based on the end users' requirement. The relation between load variation as a percentage and exergetic environmental efficiency is shown in Figure 11A. Generally, as the load reduces, the exergetic environmental efficiency reduces and the relation between them is directly proportional. Therefore, it highly recommended to operate the system at full load to achieve best performance as well as low emission per MWh.

Figure 11B shows that $\mathrm{CO}_{2}$ intensity increases with increase in ambient temperature. That may be attributed to the level of reduction in net power output being greater than the fuel reduction. The reduction in net power output results from the increase in the compressor's power consumption due to the decrease in air density. Thus, the net power output will reduce as ambient temperature rises. The reduction in fuel consumption is mainly due to raising the compressed air temperature at the exit of high-pressure compressor.

The system's environmental impact is more sensitive to load variation than ambient temperature change due to the intercooling effect and the cogeneration system is more environmentally favourable in comparison with ICGT standalone. 


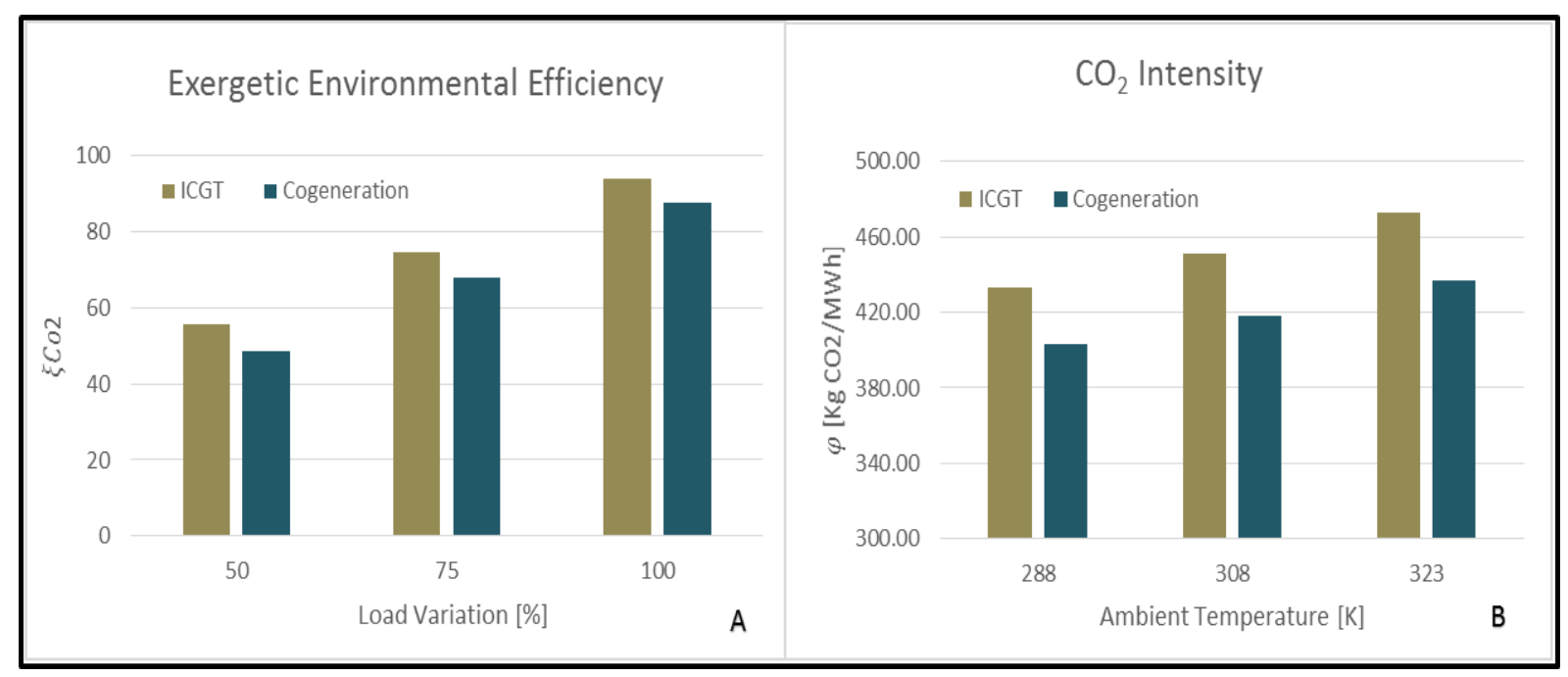

Figure 11 :Enviromental impact for ICGT and cogeneration plant A) Exergetic-environmental efficiency and $\mathrm{B}) \mathrm{CO}_{2}$ intensity.

\section{5- Conclusion}

This work presents an energetic and exergetic analysis of cogeneration plant based on an ICGT and a large RO desalination unit. The IPSEpro software was used for modelling and analyzing the proposed system. The most recently published data were used to evaluate the thermophysical properties of seawater treating it as a real mixture. The extracted exergetic data shows good agreement with the manufacturer's data and recent studies presented in Mistry et al. (2011) and Kempton et al. (2010).

The analysis confirmed that the combustion chamber has the highest level of irreversibilities followed by the RO unit and LPT, representing over $82.7 \%$ of total exergy destruction. The high-pressure pump, membrane modules and ERD are the main causes of exergy loss in the RO unit. The exergetic efficiency of a cogeneration plant is about $47.6 \%$ with advantages of high performance for separated systems and a shorter installation period than other systems for power and water generation.

It has been demonstrated that exergetic efficiency increased as the load and pressure ratio increased; the relation between them is directly proportional. Rising feed water temperature, significantly improved RO unit efficiency but, as a whole, the cogeneration plant was almost 
unaffected. Enhancement of the ICGT engine performance contributes much more than improving the desalination unit to cogeneration plant performance, a high electrical power to water ratio always recommended. Maintaining a full load on the ICGT is important for good plant performance. The intercooled system reduces or limits the ambient temperature effect on the system and low values are more favourable. The cogeneration proposed system is considered more sustainable with respect to separated systems.

\section{Acknowledgments}

The authors wish to thank the Ministry of Electricity and Water in Kuwait for its assistance and support in the current work.

\section{Reference}

Ahrendts, J. (1980). “Reference State.'” Energy, 5, 667-677.

Aljundi, I. H. (2009). "Second-Law Analysis of a Reverse Osmosis Plant in Jordan." Desalination, 239(1-3), 207-215.

Almutairi, A., Pericles, P., and Al-Mutawa, N. (2015a). “Exergetic and Environmental Analysis of 100 MW Intercooled Gas Turbine Engine." 7th International Exergy, Energy and Environment Symposium, Valenciennes - France.

Almutairi, A., Pilidis, P., and Al-Mutawa, N. (2015b). "Energetic and Exergetic Analysis of Combined Cycle Power Plant: Part-1 Operation and Performance." Energies, 8(12), 14118-14135.

Al-Sulaiman, F., Hamdullahpur, F., and Dincer, I. (2011). "Performance Comparison of Three Trigeneration Systems Using Organic Rankine Cycles.”' Energy, 36(9), 5741-5754.

Al-Weshahi, M., Anderson, A., Tian, G., and Makhdoum, B. (2013). "Validation of Simulation Model for Cogeneration Power and Water Desalination Plant." International Journal of Modeling and Optimization, 3(1), 46-51.

Al-Zahrani, a., Orfi, J., Al-Suhaibani, Z., Salim, B., and Al-Ansary, H. (2012). "Thermodynamic Analysis of a Reverse Osmosis Desalination Unit with Energy Recovery System." Procedia Engineering, 33, 404-414.

Aydin, H. (2013). "Exergetic Sustainability Analysis of LM6000 Gas Turbine Power Plant with Steam Cycle." Energy, 57, 766-774.

Bejan, A., Tsatsaronis, G., and Michael, M. (1996). “Thermal Design and Optimization.” John Wiley \& Sons.

Cerci, Y. (2002). " Exergy Analysis of a Reverse Osmosis Desalination Plant in California." Desalination, 142(3), 257-266.

Cooper, J. R., and Dooley, D. R. (2007). "The International Association for the Properties of Water and Steam. Revised Release on the IAPWS Industrial Formulation 1997 for the Thermodynamic Properties of Water and Steam" Technical Report, [Online], Available: www.iapws.org. 
Culkin, F., and Ridout, P. S. (1998). "Stability of IAPSO Standard Seawater." Journal of Atmospheric and Oceanic Technology, 15(4), 1072-1075.

Darwish, M. A. (2014). "Thermal Desalination in GCC and Possible Development.' Desalination and Water Treatment, 52(1-3), 27-47.

Dashtpour, R., \& Al-zubaidy, S. N. (2012). "Energy Efficient Reverse Osmosis Desalination Process." International Journal of Environmental Science and Development, 3(4), 339-345.

Dincer, I., and Rosen, M. A. (2013). "Exergy, Energy, Environment and Sustainable Development." Elsevier Ltd.

El-Emam, R. S., and Dincer, I. (2014). "Thermodynamic and Thermoeconomic Analyses of Seawater Reverse Osmosis Desalination Plant with Energy Recovery.” Energy, 64, 154-163.

Farooque, A. M., Jamaluddin, A. T. M., Al-Reweli, A. R., Jalaluddin, P. A. M., Al-Marwani, S. M., AlMobayed, A. A., and Qasim, A. H. (2008) . "Parametric Analyses of Energy Consumption and Losses in SWCC SWRO Plants Utilizing Energy Recovery Devices.” Desalination, 219(1-3), 137-159.

Hepbasli, A. (2008). "A Key Review on Exergetic Analysis and Assessment of Renewable Energy Resources for a Sustainable Future.' Renewable and Sustainable Energy Reviews, 12(3), 593-661.

Hou, S., Zeng, D., Ye, S., and Zhang, H. (2007). "Exergy Analysis of the Solar Multi-Effect Humidification-Dehumidification Desalination Process.' Desalination, 203(1-3), 403-409.

Kahraman, N., and Cengel, Y. (2005). "Exergy Analysis of a MSF Distillation Plant." Energy Conversion and Management, 46(15-16), 2625-2636.

Kempton, R., Maccioni, D., Mrayed, S. M., and Leslie, G. (2010). "Thermodynamic Efficiencies and GHG Emissions of Alternative Desalination Processes." Water Science and Technology: Water Supply, 10(3), 416-427.

Khaliq, A. (2015). "Energetic and Exergetic Performance Evaluation of a Gas Turbine-Powered Cogeneration System Using Reverse Brayton Refrigeration Cycle for Inlet Air Cooling." Journal of Energy Engineering, 10.1061/ (ASCE) EY.1943-7897.0000290, 04015029.

MEW (Ministry of Electricity and Water - State of Kuwait) (2008). "Shuwaikh RO Desalination Plant Technical Specification."

Midilli, A., and Dincer, I. (2009). "Development of Some Exergetic Parameters for PEM Fuel Cells for Measuring Environmental Impact and Sustainability." International Journal of Hydrogen Energy, 34(9), 3858-3872.

Mistry, K. H., McGovern, R. K., Thiel, G. P., Summers, E. K., Zubair, S. M., and Lienhard V, J. H. (2011) . "Entropy Generation Analysis of Desalination Technologies." Entropy, 13(12), 1829-1864.

Querol, E., Gonzalez-Regueral, B., and Perez-Benedito, J. L. (2012). "Practical Approach to Exergy and Thermoeconomic Analyses of Industrial Processes.' Springer Science and Business Media.

Romero-Ternero, V., García-Rodríguez, L., and Gómez, C. (2005). "Exergy Analysis of a Seawater Reverse Osmosis Plant.” Desalination, 175, 197-207.

Sharqawy, M. H., Lienhard, J. H., and Zubair, S. M. (2010). "On Exergy Calculations of Seawater with Applications in Desalination Systems.' International Journal of Thermal Sciences, 50(2), 187-196.

Sharqawy, M. H., Lienhard, J. H., and Zubair, S. M. (2011a). "Thermophysical Properties of Seawater: A Review of Existing Correlations and Data." Desalination and Water Treatment, 16 (1-3), 354-380.

Sharqawy, M. H., Zubair, S. M., and Lienhard, J. H. (2011b). "Second Law Analysis of Reverse Osmosis Desalination Plants: An Alternative Design Using Pressure Retarded Osmosis." Energy, 36(11), 6617-6626.

Wang, X., and Tang, Y. (2013). "Exergetic Analysis on the Two-Stage Reverse Osmosis Seawater Desalination System.” Desalination and Water Treatment, 51(13-15), 2862-2870. 


\begin{tabular}{cl}
$\mathrm{B}$ & Brine water flow rate \\
$\mathrm{D}$ & Distillate water flow rate \\
$\dot{\mathrm{E}}$ & Rate of exergy flow in stream \\
$\overline{\mathrm{e}}_{\mathrm{k}}^{\mathrm{ch}}$ & Specific molar chemical exergy \\
$\mathrm{F}$ & Feed water flow rate \\
$\mathrm{g}$ & Acceleration of gravity \\
$\mathrm{h}$ & Specific enthalpy \\
$h_{f g}$ & Latent heat of vaporization \\
\hline $\mathrm{LHV}$ & Low heating value in molar basis \\
$\mathrm{M}$ & Cooling seawater flow rate \\
$\dot{m}$ & Mass flow rate \\
$\dot{n}$ & Number of mole rate \\
$P$ & Pressure of the stream \\
$\dot{\mathrm{Q}}$ & Heat transfer rate \\
$R$ & Gas constant \\
$\bar{R}$ & Universal gas constant \\
$\mathrm{S}$ & Specific entropy \\
$\dot{\mathrm{S}}$ & Entropy generation \\
$\mathrm{T}$ & Temperature of the stream \\
$y$ & Mole fraction \\
$\mathrm{V}$ & Specific volume \\
$\dot{\mathrm{w}}$ & Power \\
$\dot{\mathrm{w}}$ & Minimum work of separation
\end{tabular}

\section{Greek letters}

$\bar{\lambda} \quad$ Fuel to air ratio in molar bases

$\eta_{e x} \quad$ Exergetic Efficiency

$\mu_{\mathrm{k}} \quad$ chemical potential

$\xi_{\mathrm{CO}_{2}} \quad$ Exergetic-environmental efficiency

$\varphi_{\mathrm{ac}} \quad$ Actual mass of $\mathrm{CO}_{2}$ per $\mathrm{MWh}$

$\varphi_{\text {st }} \quad$ Stoichiometric mass of $\mathrm{CO}_{2}$ per $\mathrm{MWh}$

$\varphi_{\text {cogen }} \quad \mathrm{CO}_{2}$ intensity for cogeneration plant

\section{Subscripts}

$\begin{array}{cl}\text { ac } & \text { Actual } \\ \text { c } & \text { Cold Stream } \\ \text { ch } & \text { Chemical } \\ \mathrm{cv} & \text { Control volume } \\ \mathrm{d} & \text { Destruction } \\ \mathrm{e} & \text { Outlet } \\ \mathrm{f} & \text { Fuel } \\ \mathrm{h} & \text { Hot Stream } \\ \mathrm{i} & \text { Inlet } \\ \mathrm{k} & \text { Component } \\ \mathrm{ke} & \text { Kinetic energy } \\ \mathrm{l} & \text { Loss } \\ \mathrm{m} & \text { motive steam } \\ \mathrm{o} & \text { Reference state } \\ p & \text { Product } \\ p h & \text { Physical } \\ p e & \text { Potentials } \\ \mathrm{r} & \text { Entrained vapor } \\ \mathrm{S} & \text { Steam } \\ \mathrm{x} & \text { Total }\end{array}$




$\begin{array}{cl}\text { AFR } & \text { Air to fuel ratio } \\ \text { AC } & \text { Air compressor } \\ \text { CC } & \text { Combustion chamber } \\ \mathrm{CO}_{2} & \text { Carbon Dioxide } \\ \text { DAF } & \text { Dissolved air flotation } \\ \text { EBP } & \text { ERD booster pump } \\ \text { ERD } & \text { Energy recovery device } \\ \text { FFP } & \text { filter feed pump } \\ \text { GE } & \text { General Electric } \\ \text { GT } & \text { Gas Turbine } \\ \text { HBP } & \text { high-pressure brackish pump } \\ \text { HPC } & \text { High-Pressure compressor } \\ \text { HPP } & \text { high-pressure pump } \\ \text { HPT } & \text { High-Pressure turbine } \\ \text { ICGT } & \text { Intercooled gas turbine } \\ \text { IP } & \text { Intermediate-Pressure turbine } \\ \text { ISO } & \text { International Standards Organization } \\ \text { LP } & \text { Low-Pressure turbine } \\ \text { MED } & \text { Multi-effect desalination } \\ \text { MEW } & \text { Ministry of Electricity and Water } \\ \text { MSF } & \text { Multi Stage Flash } \\ \text { PEM } & \text { Polymer electrolyte membrane } \\ \text { PWP } & \text { Product water pump } \\ \text { PX } & \text { Pressure exchange } \\ \text { RO } & \text { Reverse osmosis } \\ \text { SSP } & \text { seawater supply pump } \\ \text { UF } & \text { Ultrafiltration } \\ \text { UFP } & \text { Ultrafiltration pump } \\ \text { WWP } & \text { Waste Water pump } \\ & \end{array}$




\section{Appendix A - Validation of Proposed Models}

In Appendix-A, the validation of the intercooled gas turbine engine LMS 100 and Al Shuwaikh RO desalination plant models with manufacturer data as illustrated in tables A-1 and A-2.

Table A-1: LMS100 published performance data with result of equivalent proposed model.

\begin{tabular}{l|c|c|c}
\multicolumn{1}{c|}{ Description } & GE & IPSEpro Model & Unit \\
\hline Power output (MW) & 98.70 & 98.80 & $\mathrm{MW}$ \\
\hline Thermal efficiency (\%) & 45.00 & 43.30 & $\%$ \\
\hline Heat rate (KJ/KWh) & 7921.00 & 8307.53 & $\mathrm{KJ} / \mathrm{KWh}$ \\
\hline Pressure ratio & 42.00 & 42.00 & - \\
\hline Exhaust Mass flow (Kg/s) & 222.00 & 222.00 & $\mathrm{Kg} / \mathrm{s}$ \\
\hline Exhaust Temperature $(\mathrm{K})$ & 685.00 & 689.00 & $\mathrm{~K}$ \\
\hline
\end{tabular}

Table A-2: The validation of AL-Shuwaikh RO Desalination Plant.

\begin{tabular}{l|c|c|c}
\hline \multicolumn{1}{c|}{ Description } & Doosan & IPSEpro Model & Unit \\
\hline Number of SWRO stages & 10 & 10 & --- \\
\hline Number of BWRO nit stages & 4 & 4 & - --- \\
\hline Seawater feed temperature & 15 & 15 & ${ }^{\circ} \mathrm{C}$ \\
\hline Seawater temperature salinity & 45000 & 45000 & $\mathrm{ppm}$ \\
\hline Design mass flow rate & 4921.1 & 4921.1 & $\mathrm{Kg} / \mathrm{s}$ \\
\hline Permeate mass flow rate & 1611.1 & 1611.1 & $\mathrm{Kg} / \mathrm{s}$ \\
\hline Rejected mass flow rate & 3342.8 & 3342.8 & $\mathrm{Kg} / \mathrm{s}$ \\
\hline SWRO permeate mass flow rate & 1750 & 1750 & $\mathrm{Kg} / \mathrm{s}$ \\
\hline SWRO bypass permeate mass flow rate & 361.1 & 361.1 & $\mathrm{Kg} / \mathrm{s}$ \\
\hline SWRO permeate mass flow rate & 1250 & 1250 & $\mathrm{Kg} / \mathrm{s}$ \\
\hline BWRO rejected mass flow rate & 138.8 & 138.8 & $\mathrm{Kg} / \mathrm{s}$ \\
\hline Permeate salinity & less than 200 & 1 less than 200 & $\mathrm{ppm}$ \\
\hline Brine salinity & 66279 & 66279 & $\mathrm{ppm}$ \\
\hline SSP discharge pressure & 2.5 & 2.5 & $\mathrm{bar}$ \\
\hline FFP discharge pressure & 5.5 & 5.5 & $\mathrm{bar}$ \\
\hline UF Backwash discharge pressure & 4.5 & 4.5 & $\mathrm{bar}$ \\
\hline ERD booster pump discharge pressure & 66.7 & 66.7 & $\mathrm{bar}$ \\
\hline SWRO HPP discharge pressure & 66.7 & 66.7 & $\mathrm{bar}$ \\
\hline BWRO HPP discharge pressure & 13.7 & 13.7 & $\mathrm{bar}$ \\
\hline SWRO recovery ratio & 42 & 42 & $\%$ \\
\hline BWRO recovery ratio & 90 & 90 & $\%$ \\
\hline
\end{tabular}




\section{Appendix B - Seawater Thermo-Physical Properties}

The thermophysical properties of seawater were determined by using a model of International Association for the Physical Sciences of the Oceans (IAPSO) (Culkin and Ridout,1998). The Gibbs energy in proposed model is a function of pressure, temperature and salinity and used to calculate thermodynamic properties. The fundamental equations details shown in 2008 issued by International Association of Properties of Water and Steam (IAPWS) (Cooper and Dooley, 2007). Sharqawy et al. (2010) proposed some correlations to calculate specific volume, specific enthalpy, specific entropy and chemical potential. These correlations validated with IAPSO and IAPWS models and showed good agreement. Table B-1 shows some constants that used to calculate thermodynamic properties.

Table B-1: Thermodynamical empirical correlation constants.

\begin{tabular}{|c|c|c|c|c|}
\hline $\mathrm{a}_{1}$ & $\mathrm{~b}_{1}$ & $\mathrm{~b}_{6}$ & $\mathrm{c}_{1}$ & $\mathrm{c}_{6}$ \\
\hline $8.02 \times 10^{2}$ & $-2.348 \times 10^{4}$ & $-4.417 \times 10^{1}$ & $-4.231 \times 10^{2}$ & $-1.443 \times 10^{-1}$ \\
\hline $\mathrm{a}_{2}$ & $\mathrm{~b}_{2}$ & $\mathrm{~b}_{7}$ & $\mathrm{c}_{2}$ & $\mathrm{c}_{7}$ \\
\hline$-2.001 \times 10^{1}$ & $3.152 \times 10^{5}$ & $2.139 \times 10^{-1}$ & $1.463 \times 10^{4}$ & $5.879 \times 10^{-4}$ \\
\hline $\mathrm{a}_{3}$ & $\mathrm{~b}_{3}$ & $\mathrm{~b}_{8}$ & $\mathrm{c}_{3}$ & $\mathrm{c}_{8}$ \\
\hline $1.677 \times 10^{-2}$ & $2.803 \times 10^{6}$ & $-1.991 \times 10^{4}$ & $-9.88 \times 10^{4}$ & $-6.111 \times 10^{1}$ \\
\hline $\mathrm{a}_{4}$ & $\mathrm{~b}_{4}$ & $\mathrm{~b}_{9}$ & $\mathrm{c}_{4}$ & $\mathrm{c}_{9}$ \\
\hline$-3.06 \times 10^{-5}$ & $-1.446 \times 10^{7}$ & $\mathrm{~b} 2.778 \times 10^{4}$ & $3.095 \times 10^{5}$ & $8.041 \times 10^{1}$ \\
\hline $\mathrm{a}_{5}$ & $\mathrm{~b}_{5}$ & $\mathrm{~b}_{10}$ & $\mathrm{c}_{5}$ & $\mathrm{c}_{10}$ \\
\hline$-1.613 \times 10^{-}$ & $7.826 \times 10^{3}$ & $9.728 \times 10^{1}$ & $2.562 \times 10^{1}$ & $3.035 \times 10^{-1}$ \\
\hline
\end{tabular}

The following equations give the specific volume (v), specific enthalpy (h) and specific entropy (s) colorations:-

$$
\begin{gathered}
v_{s w}=\frac{1}{\rho_{s w}} \\
\rho_{s w}=\rho_{w}+w_{s}\left(a_{1}+a_{2} T+a_{3} T^{2}+a_{4} T^{3}+a_{5} w_{s} T^{2}\right) \\
\rho_{w}=9.999 \times 10^{2}+2.034 \times 10^{-2} T-6.162 \times 10^{-3} T^{2}+2.261 \times 10^{-5} T^{3} \\
-4.657 \times 10^{-8} T^{4} \\
h_{s w}=h_{w}-w_{s}\left(b_{1}+b_{2} w_{s}+b_{3} w_{s}^{2}+b_{4} w_{s}^{3}+b_{5} T+b_{6} T^{2}+b_{7} T^{3}+b_{8} w_{s} T\right. \\
\left.+b_{9} w_{s}^{2} T+b_{10} w_{s} T^{2}\right) \\
h_{w}=141.355+4202.070 T-0.535 T^{2}+0.004 T^{3}
\end{gathered}
$$




$$
\begin{gathered}
s_{s w}=s_{w}-w_{s}\left(c_{1}+c_{2} w_{s}+c_{3} w_{s}^{2}+c_{4} w_{s}^{3}+c_{5} T+c_{6} T^{2}+c_{7} T^{3}+c_{8} w_{s} T\right. \\
\left.+c_{9} w_{s}^{2} T+c_{10} w_{s} T^{2}\right) \\
s_{w}=0.1543+15.383 T-2.996 \times 10^{-2} T^{2}+8.193 \times 10^{-5} T^{3}-1.37 \times 10^{-7} T^{4}
\end{gathered}
$$

Where the subscripts (w) and (sw) represent pure water and saline water. The salt concentration symbolized by $w_{s}$ in $\mathrm{kg}_{\mathrm{s}} / \mathrm{kg}_{\mathrm{sw}}$. The temperture unit in all above equation should be in Celsius and the outcome unit for the specific volume, specific enthalpy and specific entropy will be $\mathrm{m}^{3} / \mathrm{kg}, \mathrm{J} / \mathrm{kg}$ and $\mathrm{J} /(\mathrm{kg} . \mathrm{k})$.

The chemical potentials of seawater can be calculated from the derivative of Gibbs energy function as shown in the following equations:-

$$
\begin{gathered}
\mu_{w}=\frac{\partial G_{s w}}{\partial m_{w}}=g_{s w}-w_{s} \frac{\partial g_{s w}}{\partial w_{s}} \\
\mu_{s}=\frac{\partial G_{s w}}{\partial m_{s}}=g_{s w}+\left(1-w_{s}\right) \frac{\partial g_{s w}}{\partial w_{s}} \\
g_{s w}=h_{s w}-(T+273.15) s_{s w} \\
\frac{\partial g_{s w}}{\partial w_{s}}=\frac{\partial h_{s w}}{\partial w_{s}}-(T+273.15) \frac{\partial s_{s w}}{\partial w_{s}} \\
-\frac{\partial h_{s w}}{\partial w_{s}}=b_{1}+2 b_{2} w_{s}+3 b_{3} w_{s}^{2}+4 b_{4} w_{s}^{3}+b_{5} T+b_{6} T^{2}+b_{7} T^{3} \\
\quad+2 b_{8} w_{s} T+3 b_{9} w_{s}^{2} T+2 b_{10} w_{s} T^{2} \\
-\frac{\partial s_{s w}}{\partial w_{s}}=c_{1}+2 c_{2} w_{s}+3 c_{3} w_{s}^{2}+4 c_{4} w_{s}^{3}+c_{5} T+c_{6} T^{2}+c_{7} T^{3} \\
\left.+2 c_{8} w_{s} T+3 c_{9} w_{s}^{2} T+4 c_{10} w_{s} T^{2}\right)
\end{gathered}
$$

Where $g_{s w}$ is the specific Gibbs energy of seawater. 


\section{Appendix C - Molar and Energy Analysis}

The fuel mass flow rate in ICGT engine vary with a change in operating conditions. The compressed air temperature inlet to annular combustor significantly effect on the air to fuel ratio (AFR). The ICGT can be operated by using natural gas or liquid fuel. In the current study, the former were used the following composition.

Table C-1. Natural gas components molar fraction.

\begin{tabular}{cc}
\hline Component & Molar fraction $(\%)$ \\
\hline Methane $\left(\mathrm{CH}_{4}\right)$ & 93.34 \\
\hline Ethane $\left(\mathrm{C}_{2} \mathrm{H}_{6}\right)$ & 0.211 \\
\hline Propane $\left(\mathrm{C}_{3} \mathrm{H}_{8}\right)$ & 0.029 \\
\hline Nitrogen $\left(\mathrm{N}_{2}\right)$ & 6.42 \\
\hline
\end{tabular}

The air stream composition in the in the cold section is given in Table C-2.

Table C-2. Air components molar fraction.

\begin{tabular}{cc}
\hline Component & Molar fraction (\%) \\
\hline Nitrogen $\left(\mathrm{N}_{2}\right)$ & 77.48 \\
\hline Oxygen $\left(\mathrm{O}_{2}\right)$ & 20.59 \\
\hline Water $\left(\mathrm{H}_{2} \mathrm{O}\right)$ & 1.9 \\
\hline Carbon dioxide $\left(\mathrm{CO}_{2}\right)$ & 0.03 \\
\hline
\end{tabular}

The stoichiometric AFR value were determined by applying Molar analyses as explained (Bejan et al. , 1996). The molar air to fuel is given by:

$$
\frac{1}{\bar{\lambda}}=\frac{\dot{n}_{a}}{\dot{n}_{f}}
$$

Where $\dot{n}$ and $\bar{\lambda}$ refer to rate of number of mole and fuel-to-air ratio. Where $\dot{n}$ and $\bar{\lambda}$ refer to the rate of a number of moles and fuel-to-air ratio. The subscripts (a) and (f) represent air and fuel respectively. The rate of number of moles defined as a ratio of mass flow rate to molecular weight and can be expressed by: 


$$
\dot{n}=\frac{\dot{m}}{\mathrm{M}}
$$

The combustion reaction for case study can be written in term of mole fractions (y) and takes the following form:

$$
\bar{\lambda}\left[\begin{array}{c}
0.9334 \mathrm{CH}_{4} \\
0.00211 \mathrm{C}_{2} \mathrm{H}_{6} \\
0.00029 \mathrm{C}_{3} \mathrm{H}_{8} \\
0.0642 \mathrm{~N}_{2}
\end{array}\right]+\left[\begin{array}{c}
0.7748 \mathrm{~N}_{2} \\
0.2059 \mathrm{O}_{2} \\
0.019 \mathrm{H}_{2} \mathrm{O} \\
0.0003 \mathrm{CO}_{2}
\end{array}\right] \rightarrow(1+\bar{\lambda})\left[\begin{array}{c}
\mathrm{y}_{\mathrm{N}_{2}} \mathrm{~N}_{2} \\
\mathrm{y}_{\mathrm{O}_{2}} \mathrm{O}_{2} \\
\mathrm{y}_{\mathrm{H}_{2} \mathrm{O}} \mathrm{H}_{2} \mathrm{O} \\
\mathrm{y}_{\mathrm{CO}_{2}} \mathrm{CO}_{2}
\end{array}\right]
$$

The air to fuel ratio can be calculated by using energy balance equation between fuel and difference in enthalpies due to heat addition. The reactant and product enthalpies were determined by applying ideal gas mixture principles on combustor chamber upstream and downstream conditions. The energy rate equation for ICGT rotating components under adiabatic condition is given by:

$$
\begin{gathered}
\text { Compressor: } \dot{W}_{A c}=\dot{m}_{a}\left(h_{e-} h_{i}\right) \\
\text { Gas Turbine: } \dot{W}_{G T}=\dot{m}_{p}\left(h_{i-} h_{e}\right)
\end{gathered}
$$

The rate of heat transfer in the combustor can be calculated from molar low heating value of natural gas with assuming $2 \%$ as a heat loss using the following expression:

$$
\dot{Q}_{c v}=-0.02 \dot{n}_{f} \overline{L H V}=\dot{n}_{a}(-0.02 \bar{\lambda}) \overline{L H V}
$$

The energy balance equations for the adiabatic pumps are given by:

$$
\text { Pump } \quad: \dot{W}_{p}=\dot{m}_{w}\left(h_{e-} h_{i}\right)
$$


2017-03-14

\title{
Exergetic and sustainability analysis of an intercooled gas turbine cogeneration plant with reverse osmosis desalination system
}

\author{
Almutairi, Abdulrahman
}

American Society of Civil Engineers

\begin{abstract}
Almutairi A, Pilidis P, Al-Mutawa N, Al-Weshahi M. (2017) Exergetic and sustainability analysis of an intercooled gas turbine cogeneration plant with reverse osmosis desalination system, Journal of Energy Engineering, Volume 143, Issue 5, October 2017, Article number 04017016 http://dx.doi.org/10.1061/(ASCE)EY.1943-7897.0000445

Downloaded from Cranfield Library Services E-Repository
\end{abstract}

